\title{
The Upper Palaeolithic site of Kalavan 1 (Armenia): An Epigravettian settlement in the Lesser Caucasus
}

Article in Journal of Human Evolution · September 2013

DOI: 10.1016/j.jhevol.2013.07.011 · Source: PubMed

CITATIONS

13

10 authors, including:

\section{Adrian Balasescu}

Muzeul Naţional de Istorie a României

138 PUBLICATIONS 429 CITATIONS

SEE PROFILE

\section{Ollivier Vincent}

French National Centre for Scientific Research 98 PUBLICATIONS 272 CITATIONS

SEE PROFILE

\section{READS}

216

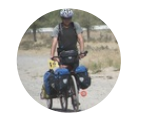

Sébastien Joannin

Université de Montpellier

68 PUBLICATIONS 851 CITATIONS

SEE PROFILE

\section{Chataigner C.}

French National Centre for Scientific Research 75 PUBLICATIONS 520 CITATIONS

SEE PROFILE

Some of the authors of this publication are also working on these related projects:

Etude par télédétection aérienne (LIDAR) des microreliefs fossiles du massif forestier de Compiègne (Oise) View project 


\title{
The Upper Palaeolithic site of Kalavan 1 (Armenia): An Epigravettian settlement in the Lesser Caucasus
}

\author{
Cyril Montoya $^{\mathrm{a}, \mathrm{b}, *}$, Adrian Balasescu ${ }^{\mathrm{c}}$, Sébastien Joannin ${ }^{\mathrm{d}, \mathrm{e}}$, Vincent Ollivier ${ }^{\mathrm{f}, \mathrm{g}}$, \\ Jérémie Liagre ${ }^{\mathrm{h}}$, Samvel Nahapetyan ${ }^{\mathrm{i}}$, Ruben Ghukasyan ${ }^{\mathrm{j}}$, David Colonge ${ }^{\mathrm{k}}$, \\ Boris Gasparyan ${ }^{\mathrm{j}}$, Christine Chataigner ${ }^{1}$ \\ ${ }^{a}$ Aix Marseille Université, CNRS, MCC, LAMPEA UMR 7269, 13094 Aix-en-Provence, France \\ ${ }^{\mathrm{b}}$ DRAC Picardie, Service Régional de l'Archéologie, 5 rue Henri Daussy, 80000 Amiens, France \\ ${ }^{\mathrm{c}}$ National Museum of Romanian History, 12 Calea Victoriei, Bucarest, Romania \\ ${ }^{\mathrm{d}}$ CNRS UMR 5276 LGL TPE, Université Lyon 1, 2 rue Dubois, 69622 Villeurbanne Cedex, France \\ e CNRS UMR 6249, Laboratoire Chrono-Environnement, Université de Franche-Comté, 16 route de Gray, 25030 Besançon, France \\ ${ }^{\mathrm{f}}$ Collège de France, PrOCauLAC-UMR 7192-CNRS Proche-Orient, Caucase: Langues, Archéologie, Cultures, 52 rue du Cardinal Lemoine, 75005 Paris, France \\ ${ }^{g}$ Aix Marseille Université, CNRS, MCC, LAMPEA UMR 7269, Maison Méditerranéenne des Sciences de l'Homme BP 647, 5 rue du Château de l'Horloge, 13094 \\ Aix en Provence Cedex 2, France \\ ${ }^{\mathrm{h}}$ Service Archéologique de la Ville de Lyon, 10 rue Neyret, 69001 Lyon, France \\ ${ }^{\mathrm{i}}$ Department of Cartography and Geomorphology, Yerevan State University, Alek. Manukyan 1, 375019 Yerevan, Armenia \\ ${ }^{\mathrm{j}}$ Institute of Archaeology and Ethnology, National Academy of Sciences of Republic of Armenia, Charents 15, 375019 Yerevan, Armenia \\ ${ }^{\mathrm{k}}$ TRACES-UMR 5608 CNRS, Maison de la Recherche, Université de Toulouse II-Le Mirail, 5 allée Antonio Machado, 31058 Toulouse, France \\ ${ }^{1}$ Archéorient UMR 5133 CNRS, Maison de l'Orient et de la Méditerranée - Jean Pouilloux, 7 rue Raulin, 69365 Lyon, France
}

\section{A R T I C L E I N F O}

\section{Article history:}

Received 21 January 2012

Accepted 15 July 2013

Available online 18 September 2013

\section{Keywords:}

Lesser Caucasus

Armenia

Upper Paleolithic

Epigravettian

Lithic

Fauna

\begin{abstract}
A B S T R A C T
The open-air site of Kalavan 1 is located in the Aregunyats mountain chain (at $1640 \mathrm{~m}$ above sea level) on the northern bank of Lake Sevan. It is the first Upper Palaeolithic site excavated in Armenia. Led by an Armenian-French team, several excavations (2005-2009) have revealed a well preserved palaeosoil, dated to around 14,000 BP (years before present), containing fauna, lithic artefacts, as well as several hearths and activity areas that structure the settlement. The initial studies enable placement of the site in its environment and justify palaeoethnological analysis of the Epigravettian human groups of the Lesser Caucasus.
\end{abstract}

(c) 2013 Elsevier Ltd. All rights reserved.

\section{Presentation}

In north-eastern Armenia, the open-air site of Kalavan 1 (1640 $\mathrm{m}$ in altitude) is located on the north shore of Lake Sevan, in the heart of the Aregunyats mountain chain and in the valley of the Barepat, which flows into the Getik river. The Getik river is one of many tributaries in the basin of the Agstev that feed the Kura river in Georgia (Fig. 1). All of these valleys serve as routes of penetration

\footnotetext{
* Corresponding author.

E-mail addresses: cyril.montoya@culture.gouv.fr (C. Montoya), abalasescu2005@ yahoo.fr (A. Balasescu), sebastien.joannin@univ-lyon1.fr (S. Joannin), vincent.ollivier@college-de-france.fr (V. Ollivier), jeremie.liagre@mairie-lyon.fr (J. Liagre), nahapetyan@ysu.am (S. Nahapetyan), robert_80kal@yahoo.com (R. Ghukasyan), david.colonge@wanadoo.fr (D. Colonge), borisg@ virtualarmenia.am (B. Gasparyan), christine.chataigner@mom.fr (C. Chataigner).
}

into the Lesser Caucasus from the alluvial plain of the middle and lower Kura valley, which crosses central Georgia and Azerbaijan. Kalavan 1 is located a few hours' walk from Lake Sevan. Its topographical position is strategic for the seasonal migrations of local mammalian fauna. The site is situated in a bottleneck, at the interface between the narrowing of the valley of the Barepat and the opening towards rolling alpine meadows whose maximum altitude approaches $2700 \mathrm{~m}$. The altitudinal limit of the forest is situated at about 2100-2200 m, but during cold episodes of the Upper Pleistocene it would have been 800-1000 m lower (Adler and Tushabramishvili, 2004).

Kalavan 1 was discovered by Ruben Ghukasyan in 2004 after earthworks were carried out during the creation of a forest track. The first archaeological investigations in the form of trial trenches were carried out in 2005 by an Armenian-French team led by B. Gasparyan (Institute of Archaeology, Yerevan) and C. Chataigner 


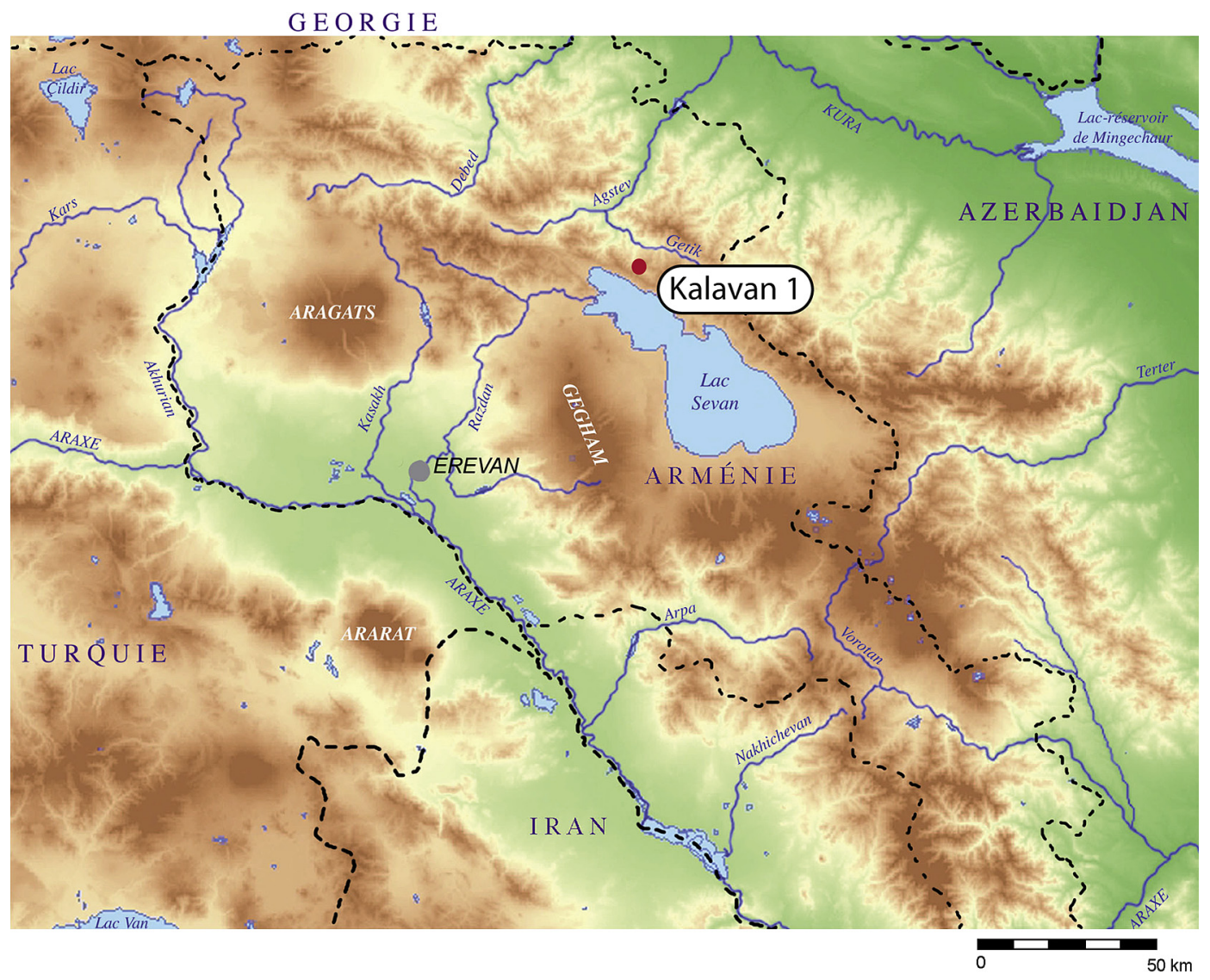

Figure 1. Location of Kalavan 1 site.

('Caucasus' mission, France; Liagre et al., 2009; Ghukasyan et al., 2011). The trenches dug in 2005 and 2006 revealed the site's archaeological potential with the discovery and excavation of an early Bronze Age necropolis (Kuro-Arax culture) as well as occupations of the Upper Palaeolithic (Liagre et al., 2009). In the same valley, a few hundred metres away from Kalavan 1, trenches dug on a spur at the edge of the Barepat and one of its tributaries brought to light an important stratigraphic sequence of the Middle Palaeolithic (MP) (Kalavan 2; Ghukasyan et al., 2011). Since the discovery of the site in 2005 and the preliminary excavation of the early Bronze Age tombs, about $40 \mathrm{~m}^{2}$ of the Epigravettian occupation has been explored.

The site of Kalavan 1 was the first Upper Palaeolithic (UP) site excavated in Armenia. More recently, the early Upper Palaeolithic site of Aghitu 3 was excavated in the Vorotan Valley in southern Armenia, but the cultural tradition of the lithic collection from the different layers remains to be characterised (Kandel et al., 2011). Although this could be due in part to limitations in the scientific research and/or the preservation of the site, palaeoclimatic factors, particularly the glacial cover of the Lesser Caucasus, certainly played an important role for human presence in these mountains during the Late Glacial Maximum (LGM). Thus, the site of Kalavan 1 could be one of the first to provide evidence for human recolonisation of the Lesser Caucasus in the Late Glacial, based on palaeoenvironmental phenomena well known in Western Europe, especially in the alpine context. Part of the 'reconquest' model of new territories is recorded for the Palaeolithic on the southern side of the Caucasus chain (Lioubine, 1992). The hypothesis of a contraction of prehistoric Caucasian human groups during the LGM in the hills of the 'Kolkhidian' region east of Georgia (Imereti) was developed by Lioubine (1992). This region would have benefited from a more moderate climate during peaks of harsh climatic conditions and thus served as a refuge zone for Palaeolithic Caucasian human groups. In Imereti, the Upper Palaeolithic appears to be well represented, with a density of open-air and cave occupations (Lioubine, 1989, 1992; Nioradze and Otte, 2000; Meshveliani et al., 2004; Nioradze, 2006). The typological homogeneity of the lithic and bone industries has certainly contributed to developing the idea of a regional culture of the Upper Palaeolithic in the Caucasus, termed 'Imeretinskaya culture' (Lioubine, 1992).

This article has two objectives. The first objective is to present the geomorphological and palaeoenvironmental context of the Kalavan 1 site and its taphonomic conditions. The second objective is to present the initial results from analysis of the socio-economic factors that contribute to knowledge of the prehistoric human groups in the Lesser Caucasus and their insertion into the cultural tradition of the Gravettian-Epigravettian area.

\section{Geomorphological context and geochronological sequence of the valley of the Barepat}

In order to better understand the relation between the terraces where the sites of Kalavan 1 and Kalavan 2 were established and the mechanisms of formation of the deposits, an exhaustive geomorphological study was carried out in 2008. The two sites lie between 1600 and $1640 \mathrm{~m}$ in altitude. They are located on the edges of watercourses (the Barepat and a tributary) that run along geological fault lines of pre-Quaternary origin, which probably shifted again during the Pleistocene and the Postglacial. The local morphostructural evolution engendered the development of a hydrographic network dependent upon the level of the Barepat's left 
bank tributaries, which are today $30 \mathrm{~m}$ higher than the main watercourse.

In this sector, five levels of Quaternary alluvial terraces can be identified (Fig. 2A):

1) terrace T1 appears to belong to the middle Pleistocene, perhaps close to the isotopic 6 stage, given its relative altitude and its geometric relationship to the lower units $(+80 \mathrm{~m}$ in relation to terrace T2);

2) terrace T2, where the Middle Palaeolithic site of Kalavan 2 is located, is linked to the MIS 3 based on the radiocarbon dating carried out (Ghukasyan et al., 2011);

3) level T3 is similarly linked to the Late Glacial (the site of Kalavan 1 is dated to about $14,000 \mathrm{BP}$ [years before present]);

4) terrace T4 appears to belong to the Holocene;
5) terrace T5 appears to belong to the historical and modern periods.

The site of Kalavan 2 was established in the alluvia of a watercourse of middle rank (4-5), a tributary on the left bank of the Barepat river (Fig. 2B). The Kalavan 1 site, however, is located on the southern edge of a small detritic cone whose origin is related to pseudo-karstic springs that engendered the formation of a relatively large ravine, on the Barepat's right bank (Fig. 2C).

Based on the field study and the radiocarbon dates, a preliminary morphogenic evolution may be proposed (Fig. 2D). This consists of four main periods of sedimentary accumulation of alluvial origin, interrupted by five major phases of linear incisions of talwegs, to which are added several other modest episodes of erosion or intra-formational incisions:
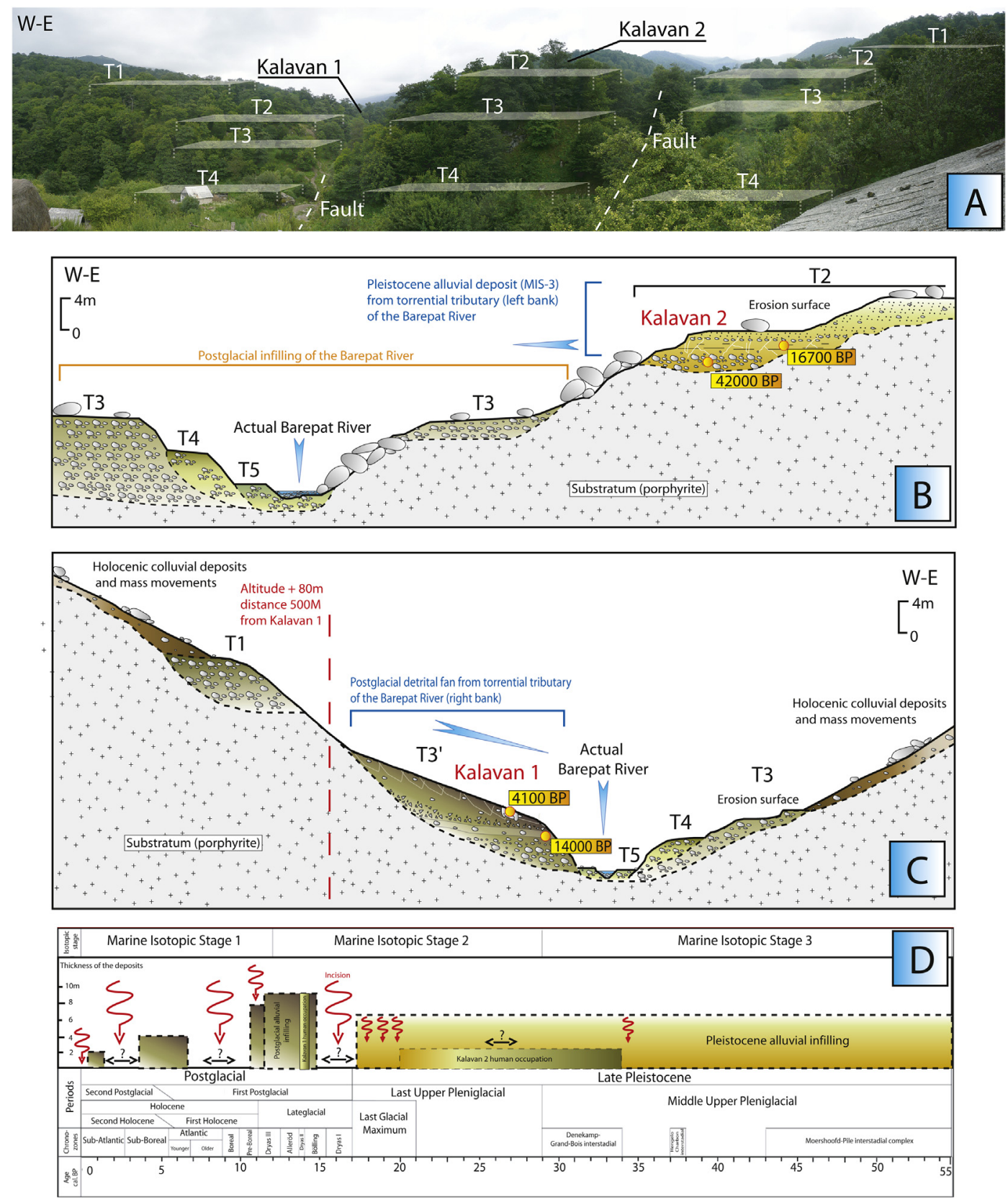

Figure 2. Proposition of an initial outline of morphogenic evolution of the Barepat valley (computer graphics V. Ollivier). 
1) development of the alluvial terrace $T 1$ and successive incision(s);

2) deposit of alluvial tables constituting terrace T2 in a consecutive cold-temperate-cold climatic context, during which Palaeolithic occupations and frequent detritic gullying episodes occurred;

3) major incision (15-20 m) at the last Upper Pleniglacial/Postglacial transition;

4) resumption of accumulation, postglacial warming and phenomena of carbonatation through 'karstic' exsurgences, Epigravettian occupations on detritic cones (embankments);

5 ) incision/erosion in levels (erosion surface), then accentuation of the incision between the Boreal and the Atlantic;

6) reversal of the morphogenic tendency in favour of deposition in valley bottoms (interlocking of terrace T4 in the underlying deposits of terrace T3) at least until 4000 BP. Increase in humidity (distribution/pattern/intensity of precipitation?) and clear appearance of many movements of masses affecting the slopes after $4000 \mathrm{BP}$;

7) incision in the second half of the Holocene;

8) constitution of the low terrace T5 (historical or modern), interlocked into $\mathrm{T} 4$;

9) beginning of the present dynamic of linear incision of talwegs.

\section{Palaeoenvironmental context}

Very few pollen data exist for the Lesser Caucasus (Joannin et al., 2010). Three samples were thus processed for pollen analysis in order to better define the palaeoenvironment in which the
Palaeolithic population lived. A standard method adapted from Cour (1974) has been used. $\mathrm{HCl}$ and $\mathrm{HF}$ treatments were followed by sieving at $160 \mu \mathrm{m}$ and $10 \mu \mathrm{m}$ and by a final enrichment procedure $(\mathrm{ZnCl} 2)$. Only one sample $\left(\mathrm{n}^{\circ} 11\right)$ provided enough pollen grains (150 grains excluding Pinus) for reliable analysis. This sample is stratigraphically situated on the archaeological layer. The main taxa found are Artemisia (40\%), Chenopodiaceae (16\%) and Asteraceae Asteroideae (13\%). An open vegetation is clearly indicated $(89 \%$ herbs and steppe). Steppe vegetation probably developed in the surroundings and at the altitude of the site. Pollen grains from temperate trees are sparse but significant (11\% of the total). Alnus, Salix and Betula (5\% altogether) probably developed in the valley bottoms as they would have needed a lower amount of water than deciduous Quercus and Corylus (6.5\% altogether). For these last two taxa, an aerial transport of pollen grains from the lowlands cannot be excluded. The pollen assemblage clearly indicates an open vegetation with occasional trees developing in favourable areas such as valley bottoms. These conditions resulted from a cold and dry climate during the Tardiglacial.

\section{Stratigraphy, taphonomic context and dating of Epigravettian occupations}

Archaeological investigations and geomorphological analyses (work of S. Nahapetyan, 2004-2006 campaign, and V. Ollivier in 2008) have brought to light the existence of a sedimentary fill made up mainly of two different dynamics (Fig. 3). This fill is confirmed by geomorphological and palaeoenvironmental studies carried out in the Lesser Caucasus and in particular in Armenia for the entire

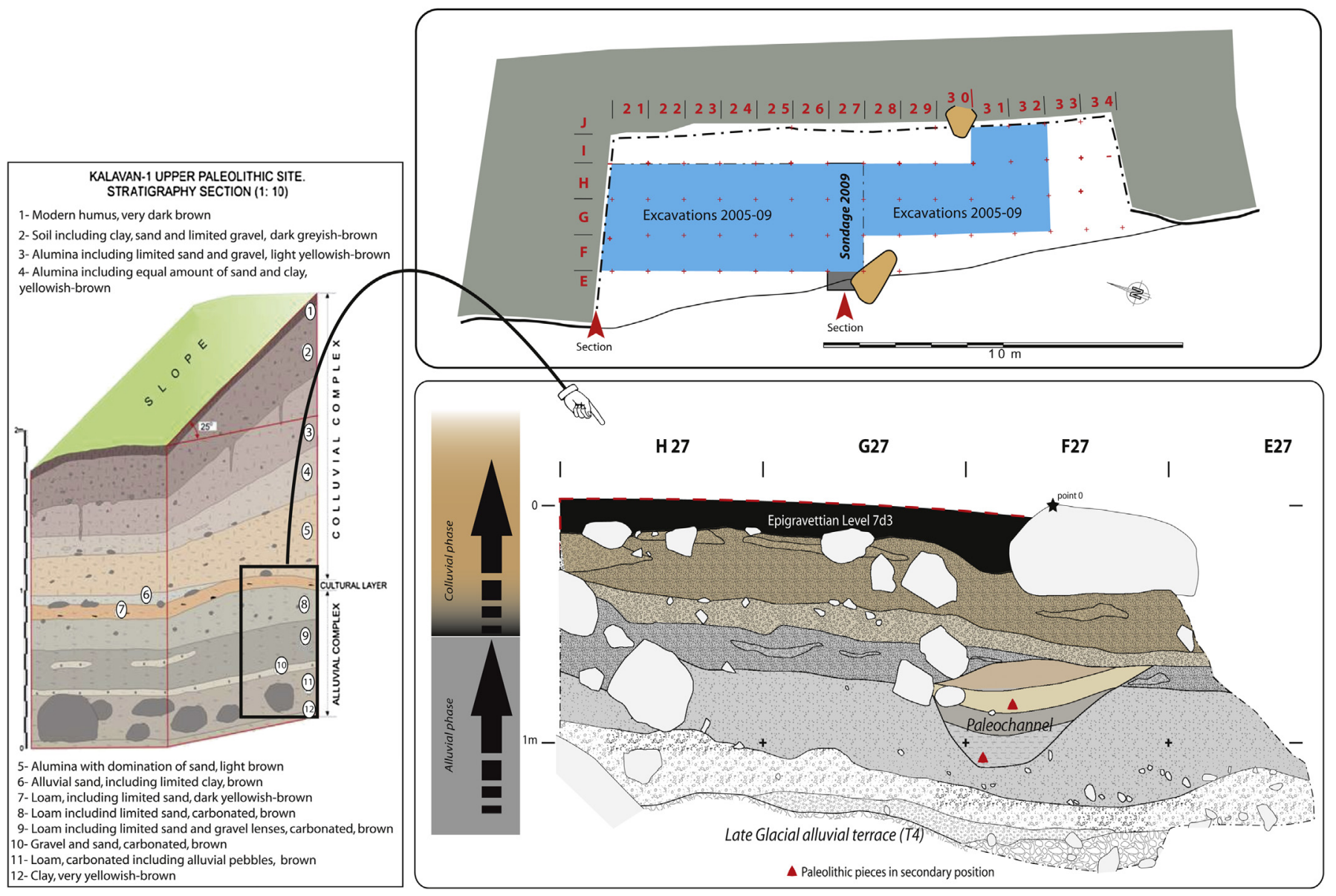

Figure 3. Kalavan 1 - stratigraphical sections (computer graphics D. Colonge, C. Montoya and S. Nahapetyan). 
Quaternary (Ollivier et al., 2010). The base of the stratigraphic sequence (sedimentary groups 12 to 8 ) consists essentially of an initial phase of early alluvial deposits of the river Barepat, which is situated today some $50 \mathrm{~m}$ below the site. The second phase (sedimentary groups 7 to 2 ) is related to the contributions from the slopes, which progressively covered the flat area of the alluvial terrace. The first Palaeolithic occupations were established at the very beginning of this colluvial dynamic (sedimentary group 7), on a sub-horizontal surface with a slight slope towards the river Barepat.

In general, investigations on the site of Kalavan 1 were constrained by safety issues regarding the very steep slope (23-25\%) above the site. The excavated zone thus developed as a band of 3$4 \mathrm{~m}$ wide by some $15 \mathrm{~m}$ long at the foot of the slope incised by the Barepat River, which flows below (Fig. 3). The most penetrating investigations (those carried out in squares I-31 and I-32) show that the site continues horizontally inside the slope.

One of the factors that influences the development of the excavation of Kalavan 1 has been to understand the conditions of burial and preservation of the Epigravettian levels. Extensive clearing of surface soil has enabled a more refined approach to the succession of Epigravettian occupations. It revealed the presence of a double vertical distribution of artefacts considered at the time of excavation to be a minimum of two distinct archaeological levels $(7 b-7 d 1$ and $7 d 3$ ) within the sedimentary whole of layer 7 (Fig. 4A). The complexity of levels $7 \mathrm{~b}-7 \mathrm{~d} 1$ and $7 \mathrm{~d} 3$, in particular their relative dissociation according to the geometry of the terrain, led us to re-evaluate the taphonomic conditions of the archaeological levels. This was facilitated by the extension of clearing in the south of the excavation. In fact, in certain zones (bands 22-23), level 7d1 appears almost in contact or in continuity with the underlying level $7 \mathrm{~d} 3$. In other sectors, these levels appear to be separated by a fine sterile sedimentary layer (7d2) up to $5 \mathrm{~cm}$ thick (Fig. 4A). This discontinuity, obvious in the field, was initially interpreted as an indication of two distinct archaeological levels within the same sedimentary matrix. Analysis of the lithic technical system revealed strong homogeneity in the modalities of production, to the point that the two levels were studied as a single entity. Quantitative and qualitative differences between $7 d 1$ and $7 d 3$ have nevertheless been observed, in particular the number of faunal remains is clearly lower in $7 \mathrm{~d} 1$.

A more refined study of the conditions of deposition will enable an appreciation of the complexity of the taphonomic phenomena that affected the Palaeolithic levels at Kalavan 1, as well as an evaluation of the quality of preservation of the different concentrations of vestiges. The study will also enable clarification of the extent of palaeosurface 7d3 (Fig. 4A). Revealed by excavation, this area of occupation fits into a slight depression between squares 21 and 27, oriented towards the river Barepat. The prehistoric group established itself in this depression. Palaeosurface $7 \mathrm{~d} 3$ lies upon a sedimentary thickness of about $10 \mathrm{~cm}$ (Fig. 4A). This vertical dispersion is most probably the result of an accumulation of seasonal freezing-melting phenomena that alternately compressed and decompressed the soils, leading to expansion of the archaeological level. This process was certainly amplified by the thermic amplitudes linked to the geographic position of the site in a mountain context $(1630 \mathrm{~m})$ and the last episodes of harsh climatic conditions in the Late Glacial.

To these taphonomic phenomena are added the classic processes of slight solifluction of the concentrated material,

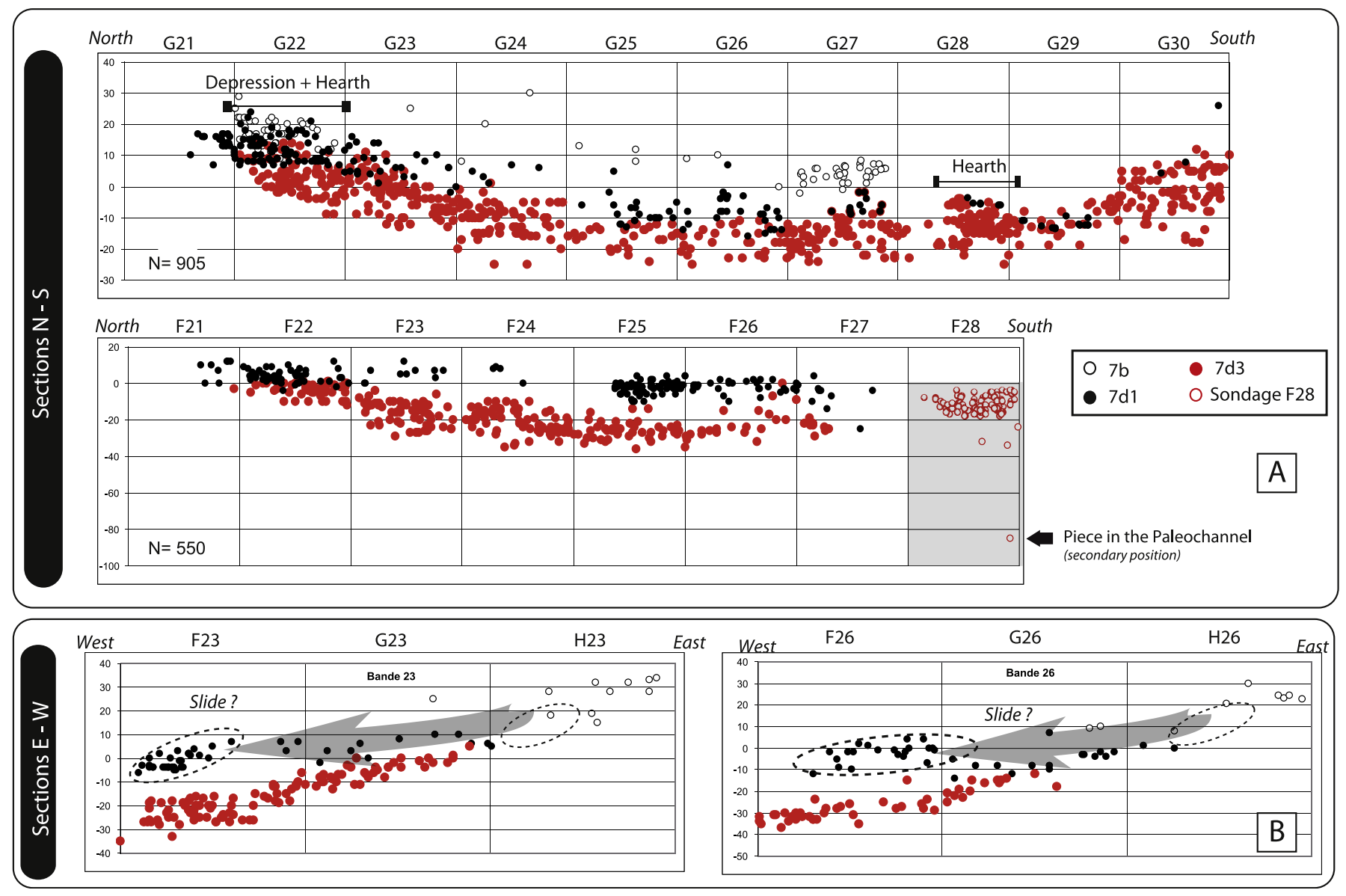

Figure 4. A - Projections of the artefacts; B - hypotheses of formation of level 7d1. 


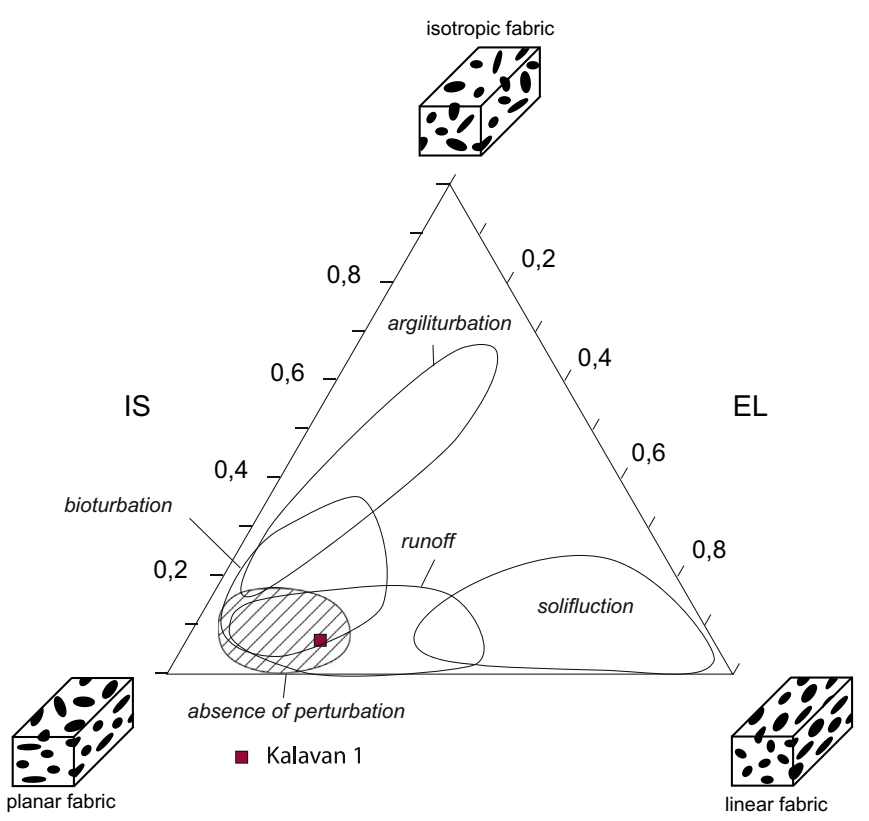

Figure 5. Fabric analysis (measurements of the orientation and slant of the pieces $N=80$ ) (by P. Bertrand).

bioturbation, and Holocene anthropic disturbances, especially the establishment of the overlying Bronze Age necropolis. In spite of all of these events, the character of palaeosurface $7 \mathrm{~d} 3$ is barely disturbed, and is clearly attested by the many anthropic structures present (hearths, heaps of faunal remains and lithics). Measurement of the orientation and angle of 80 pieces within squares $\mathrm{GH}$ 28-30 indicates that they were laid flat without preferential orientation (Fig. 5; Bertran and Texier, 1995; Bertran and Lenoble, 2002). This result confirms the in situ character of level $7 d 3$ without completely distancing the possibility of natural processes of runoff and bioturbation as well as anthropic events of short duration.

Although the archaeological value of occupation 7d3 appears clear, it is necessary to also examine level $7 \mathrm{~d} 1$. This level can be understood stratigraphically in two ways: in direct contact with the underlying level $7 \mathrm{~d} 3$, and separated from the latter by a very thin sterile layer (7d2, Fig. 4A). Aside from the low numbers in the 7d1 assemblage, this level is characterised in section by a certain discontinuity (Fig. 4B). This characteristic suggests the hypothesis of a level in secondary position, whose formation is in part related to slippage by gravity of level 7d3 (Fig. 4B). This working hypothesis, which remains to be demonstrated (in particular by refitting) could in part explain the discontinuity of distribution of level 7d1. The level 7d1 identified in the excavation is thus the result of a redistribution by solifluction of level $7 \mathrm{~d} 3$ (Fig. 4B). This postulate provides an explanation for the 'empty space' observed in this section. Thus it is also tempting to assume that level $7 \mathrm{~b}$, situated generally in the upper part, could be the continuation of $7 \mathrm{~d} 3$ (Fig. 4B).

\section{Dating}

Eight AMS dates were obtained from the Epigravettian levels of Kalavan 1. Seven measurements were made on bone fragments (one on burned bone) from the main archaeological horizon $7 \mathrm{~d} 3$. The dates position the Epigravettian occupation(s) around 14,000 BP non cal. (Fig. 6). This coherence is supported by the techno-typological homogeneity of the lithic assemblage. A single date appears to disagree with the group previously defined. This is a carbon sample taken from level 7d1 (Fig. 6). This discordance may be explained by the different post-depositional disturbances revealed by the taphonomic analysis within this level.

The dates obtained, compared to the recorded climatic curves, enable the placement of the Epigravettian occupation at Kalavan 1 within the climatic amelioration (Greenland Interstadial 1E-1D; Walker et al., 1999). This period of warming probably played a major role in the re-colonisation by both mammalian fauna and the prehistoric human groups of the Lesser Caucasus mountains. However, the difficult climatic conditions of the Late Glacial in the Lesser Caucasus would have prevented occupation during the winter months.

\section{The lithic technical sub-system}

The raw materials exploited

The examination of a sample of 621 pieces shows that the lithic collection consists of pieces made from approximatively $39 \%$ local

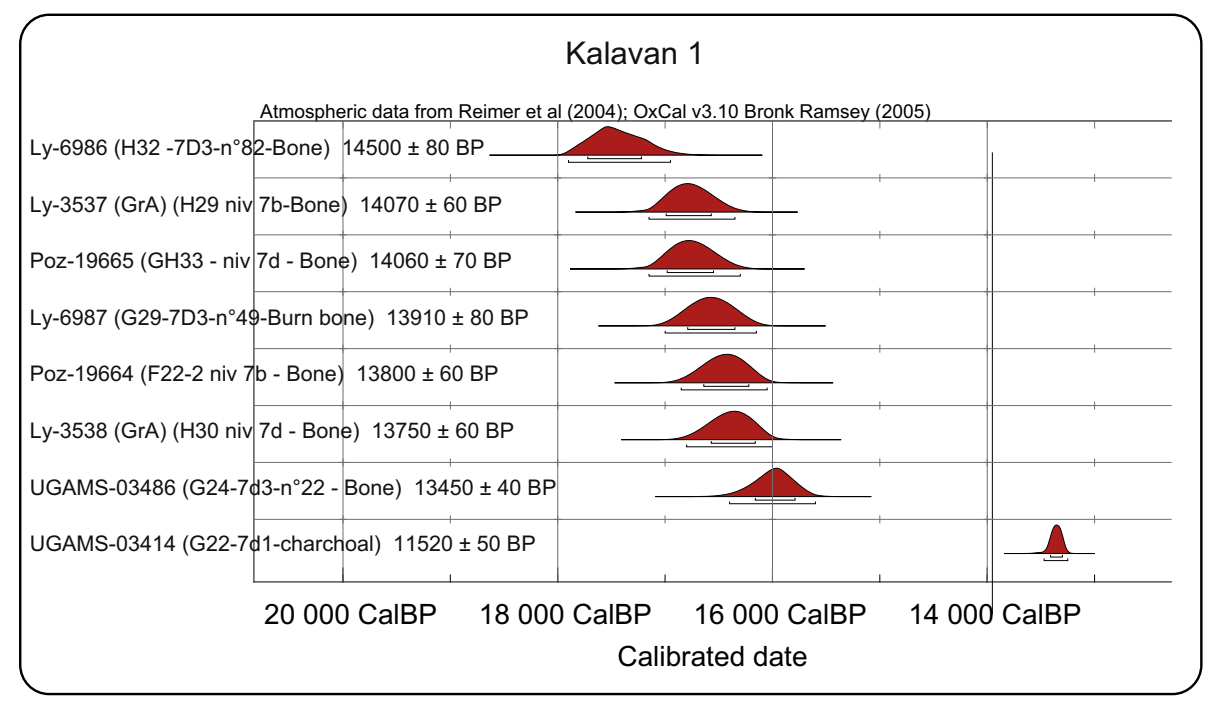

Figure 6. Radiometric measurements. 
siliceous rocks and $58 \%$ obsidian, the rest being flint $(2.9 \%)$, for which the source remains to be defined.

The local raw materials were determined to have come from the area around the site, varying from a few hundred metres to a maximum of $4 \mathrm{~km}$ (Liagre et al., 2009). Most of the materials came from nearby in the valley of the Barepat, upstream or downstream from the archaeological site. They are mainly siliceous limestone and jaspers, quite suitable for knapping, whose colours vary from green to red-mauve to black. The materials were collected in the form of blocks from the deposit as well as in the form of pebbles in secondary position, probably from the Barepat River below.
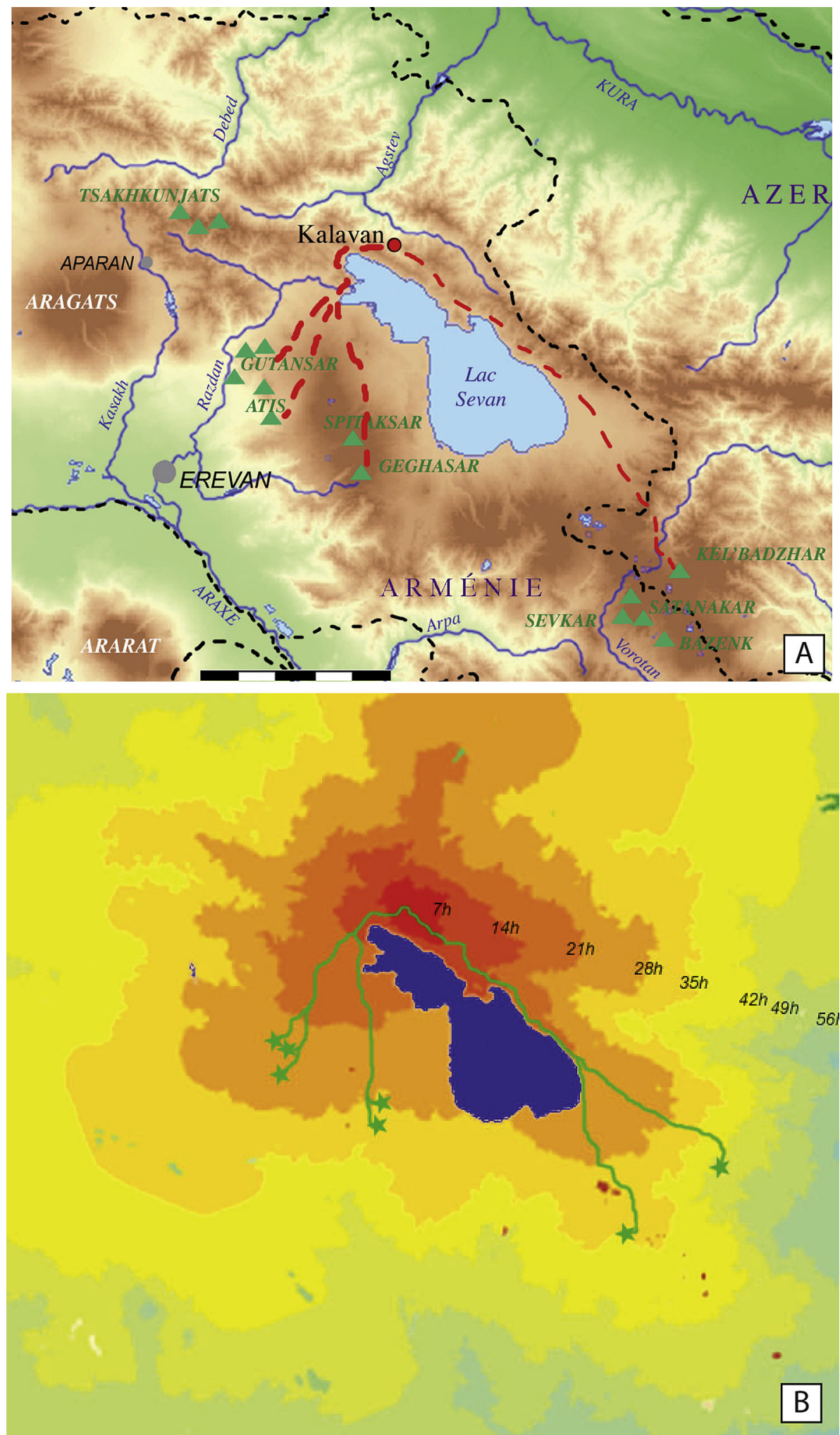

Figure 7. A - Origin of the raw materials exploited; B - estimates of the distances covered (Barge and Chataigner, 2003, 2004). 
The variety in the obsidian found at Kalavan (translucent, smoky grey, brilliant black, matt, red, speckled brown...) suggests a diversity of sources, although one deposit can include obsidian of various colours and textures. The most frequent categories are speckled red obsidian and transparent black obsidian. In an initial identification of sources of obsidian supply, 18 flakes were analysed by laser ablation inductively coupled plasma mass spectrometry (LA-ICP-MS) (Chataigner and Gratuze, 2013a,b). This method is more and more widely used to determine the elemental composition of obsidian artefacts, as it causes minimal damage to the studied objects. However, the retouched pieces were excluded from this initial sample. All of the flakes come from the same occupation level (level 7) and were selected according to the variety of obsidian.

The results of the analyses carried out by Chataigner and Gratuze (2013a,b) show that the transparent and red obsidian come from Geghasar and Gutansar, which would have been, according to the proportion of these varieties in the tools, the two sources that were most exploited (Fig. 7A). The nearby volcano of Hatis was a secondary source, while evidence for a link to the south-eastern part of the Lesser Caucasus resides in a single sample, from the region of Syunik (Fig. 7A).

Modelling of the time necessary to cover the distance between the site of Kalavan and the obsidian sources utilising a Geographic Information System shows that 23-30 hours were needed to reach the three main deposits (Gutansar, Geghasar and Hatis); that is, a walk of three to four days (Barge and Chataigner, 2003, 2004; Chataigner and Barge, 2008; Fig. 7B). The deposit of Geghasar is located at an altitude of nearly $3000 \mathrm{~m}$ and is only accessible in summer, the snow being very thick for six to eight months of the year. The obsidian from Gutansar and Hatis was obtained at a lower altitude (1500-2000 m), where these deposits could be exploited almost year-round.

The geographic locations of these sources are all to the west or south of Lake Sevan. While the human group that came to hunt at Kalavan would have been familiar with the mountains that surrounded the lake, the first analyses do not yet reveal any acquisition of obsidian from the deposits in the Tsaghkunyats range, which in distance-time is equivalent. There is also no sample from Chikiani, the large deposit located in southern Georgia, which was exploited by Upper Palaeolithic populations of this region.

The technical homogeneity of the assemblage collected since 2006 in the different levels, the evaluation of the taphonomic conditions of the archaeological deposits and the coherence of the radiometric dating argue for an overall examination of the collection with a grouping together of all of the sub-levels of layer 7 (levels 7d1 and 7d3; 2006-2009 campaigns; Table 1). The goal of this technological analysis is to define the objectives and the technical modalities of production of the craftsmen of Kalavan 1. This would also enable reconstruction of the organisation of the lithic technical sub-system used by the prehistoric humans at Kalavan 1, and would attempt to place it within a systemic analysis

Table 1

Kalavan 1 collection.

\begin{tabular}{lcc}
\hline Kal. 1 - Lithic collection 2006-2009 (niv. 7d1 and 7d3) & \multicolumn{1}{c}{$\%$} \\
\hline Blades (entire and frag.) & $N$ & 6.73 \\
Bladelets (entire and frag.) & 156 & 34.53 \\
Flakes & 800 & 55.98 \\
Nucleus & 1297 & 2.46 \\
Pebbles/Percussors & 57 & 0.30 \\
Total & 7 & 100.00 \\
\hline
\end{tabular}

integrating all of the activities engaged in by the human group in the camp.

\section{The retouched tools}

The selection for retouched tools mainly concerned those made on regular blanks of blades and bladelets. However, two cases of selection of flakes for the fabrication of an end-scraper and a burin were observed.

A count of all of the retouched pieces shows a large proportion of bladelet blanks among the tools, particularly the backed points. The latter represent more than half of the retouched tools $(51.2 \%$; Table 2 and Fig. $8 n^{\circ} 1-23$ ). No geometric armature was observed at Kalavan 1. The straight-backed points or microgravettes dominate this corpus ( $N=27$ whole pieces and fragments; Table 2 and Fig. 8). The sample is, however, too limited to evaluate precisely the concept that motivated their fabrication (Montoya, 2002, 2004). On the few whole examples ( $N=5$; Fig. $\left.8 n^{\circ} 1-5\right)$, a straight-backed edge was clearly sought. It is sometimes noted that, to improve the sharpness of the point, the straight back slightly converges with its mesio-distal part to obtain a sub-rectilinear delineation. Unlike some microgravettes from Dzudzuana cave Unit B (Bar-Yosef et al., 2011), no basal truncations occur in the collection. The creation of an inversed basal retouch on microgravette points is often related to the profile correction of the sharp edge, and thus does not have a typological value but rather a functional value (Montoya, 2002, 2004).

Despite some typological variation, these microgravettes are comparable with those that characterise the lithic assemblages of Caucasus LGM and Epipalaeolithic sites (Nioradze and Otte, 2000; Meshveliani et al., 2004, 2007; Nioradze, 2006; Bar-Yosef et al., 2011; Golovanova et al., 2012). The dimensions of these points vary from 22 to $29 \mathrm{~mm}$ in length and 4 to $6 \mathrm{~mm}$ in width. These points are moreover accompanied by backed bladelets $(N=11$; Fig. 8 $\mathrm{n}^{\circ} 12-23$ ), quite variable in width, between 3 and $8 \mathrm{~mm}$. The generic class of backed points represents all of the broken pieces having a backed edge $(N=23)$. There are also two examples of truncated backed bladelets. The fabrication of points on the site is attested by the presence of waste products from the manufacture of backed bladelets, called microburins of Krukowski type $(N=4)$, as well as by pieces with a technical shoulder.

The remaining tools on bladelets are represented by what are termed 'retouched bladelets' ( $N=2$; Fig. $\left.8 n^{\circ} 24-25\right)$. These are blanks having on one edge direct and/or inverse discontinuous

Table 2

Retouched tools.

\begin{tabular}{lrr}
\hline Kalavan 1 - retouched tools & $N$ & \multicolumn{1}{c}{$\%$} \\
\hline Armatures: & 63 & 51.2 \\
Backed bladelets (entire) & 11 & 8.9 \\
Backed point or microgravette (entire and frag.) & 27 & 22.0 \\
Backed bladelets (fragment) & 23 & 18.7 \\
Truncated backed bladelets & 2 & 1.6 \\
Retouched blades & 22 & 17.9 \\
Truncated blades & 5 & 4.1 \\
Notched blades & 4 & 3.3 \\
Retouch and truncate blade & 1 & 0.8 \\
End-scrapers & 12 & 9.8 \\
End-scrapers on retouch blade & 1 & 0.8 \\
Burins & 3 & 2.4 \\
Dihedral burin & 2 & 1.6 \\
Microburin of Krukowski & 4 & 3.3 \\
Retouched bladelets & 2 & 1.6 \\
Truncated bladelets & 2 & 1.6 \\
Splintered pieces & 2 & 1.6 \\
Total & 123 & 100.0 \\
\hline
\end{tabular}



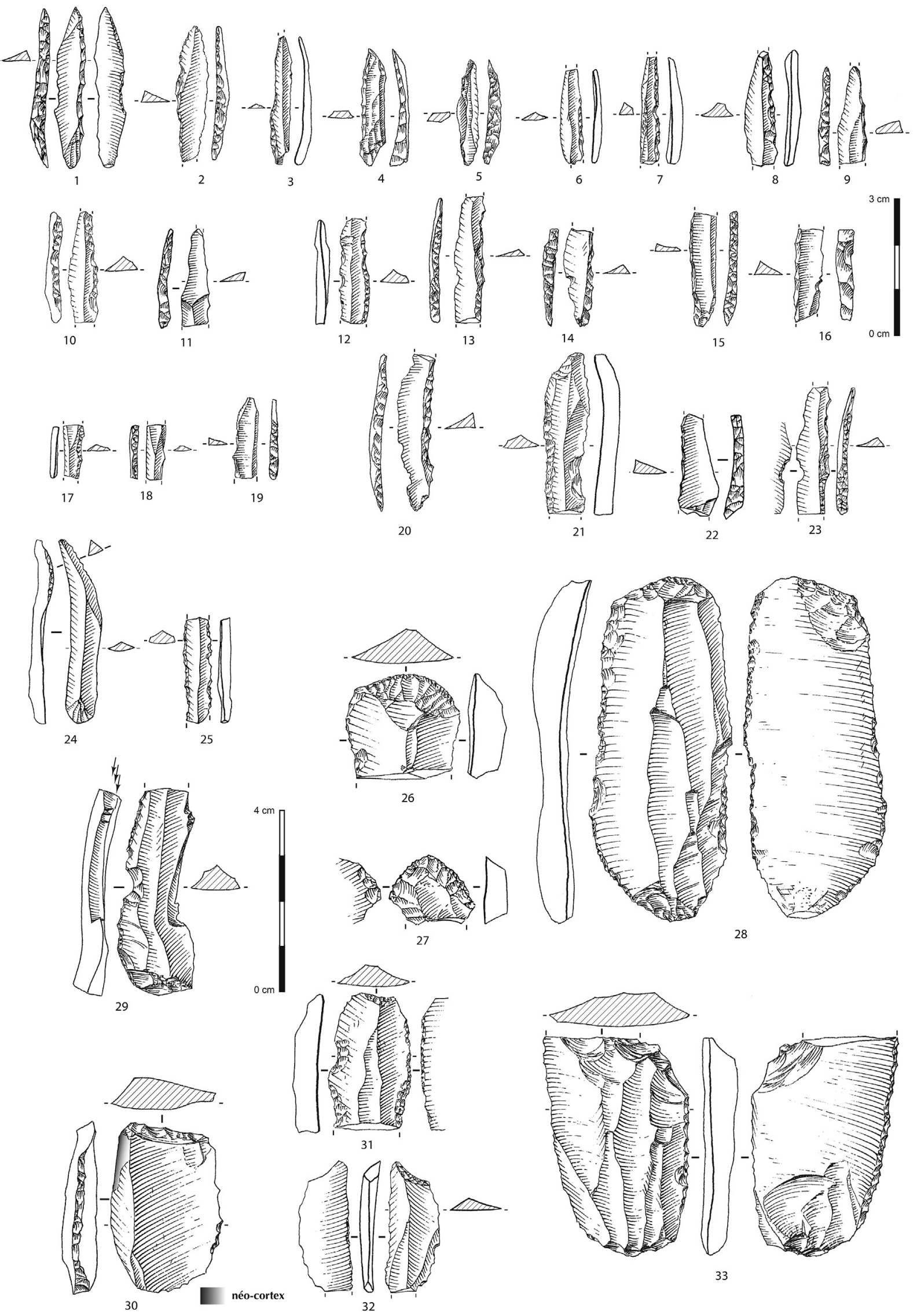

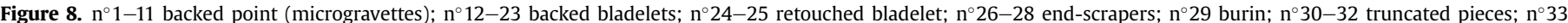
splintered pieces (Drawings by G. Devilder). 

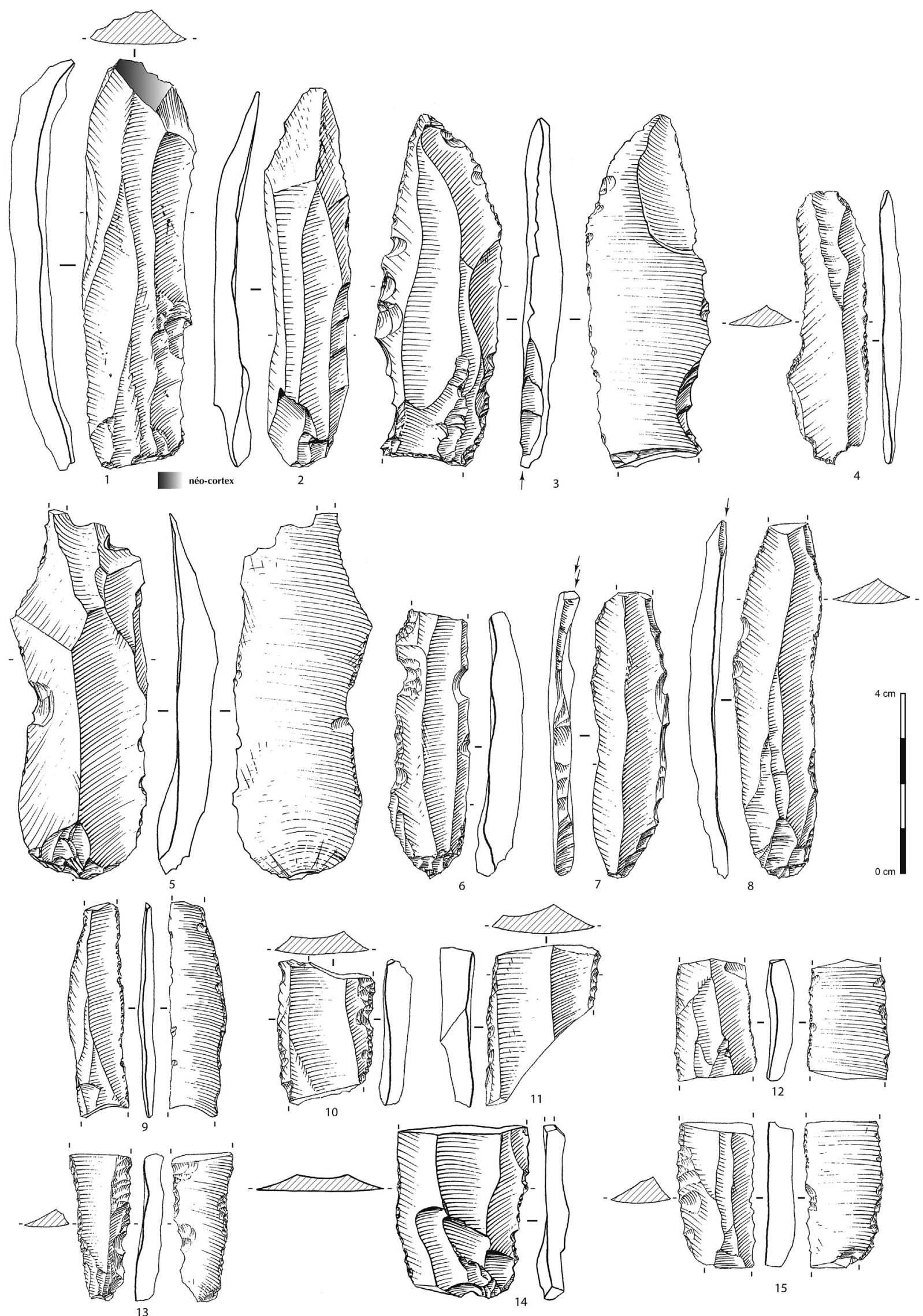

Figure 9. Retouched blades (3,7,8 Burins) (drawings by G. Devilder). 


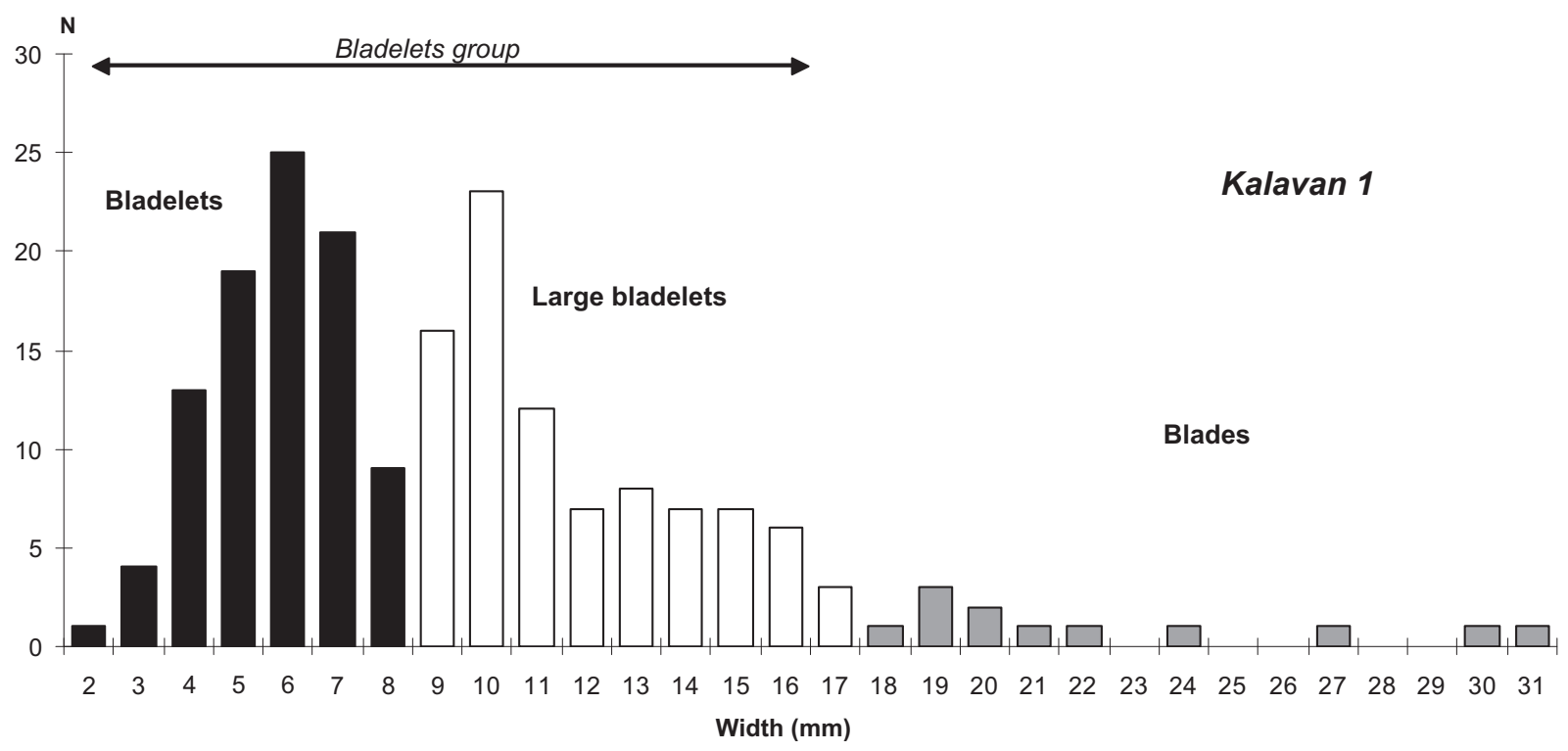

Figure 10. Objectives of the lithic production $(N=193$ blanks).

retouch comparable with a retouch probably related to their use. These same typological characteristics, on the distal part of the blank, are also visible on two truncated bladelets (Fig. $8 n^{\circ} 31-32$ ).

The blades or blade fragments are retouched blades $(N=22$; Fig. 9) but were also used for making end-scrapers and burins
(Figs. 10 and 11). Like the bladelets, the retouched blades have on at least one of their edges retouch that is inverse and/or direct, total or partial, discontinuous or continuous with irregular amplitude (Fig. 11). The heterogeneity in the retouch renders any coherent typological classification difficult, but argues for traces related to

\section{Kalavan 1 - Organisation of lithic production}

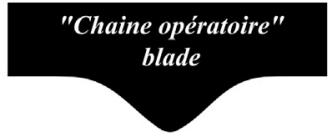

Technical modality?

Hypothesis of outsite production (lack of subproducts)

Import of unretouched blade?
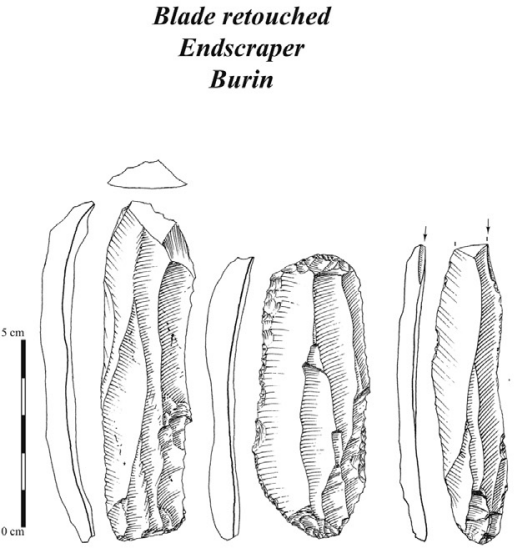
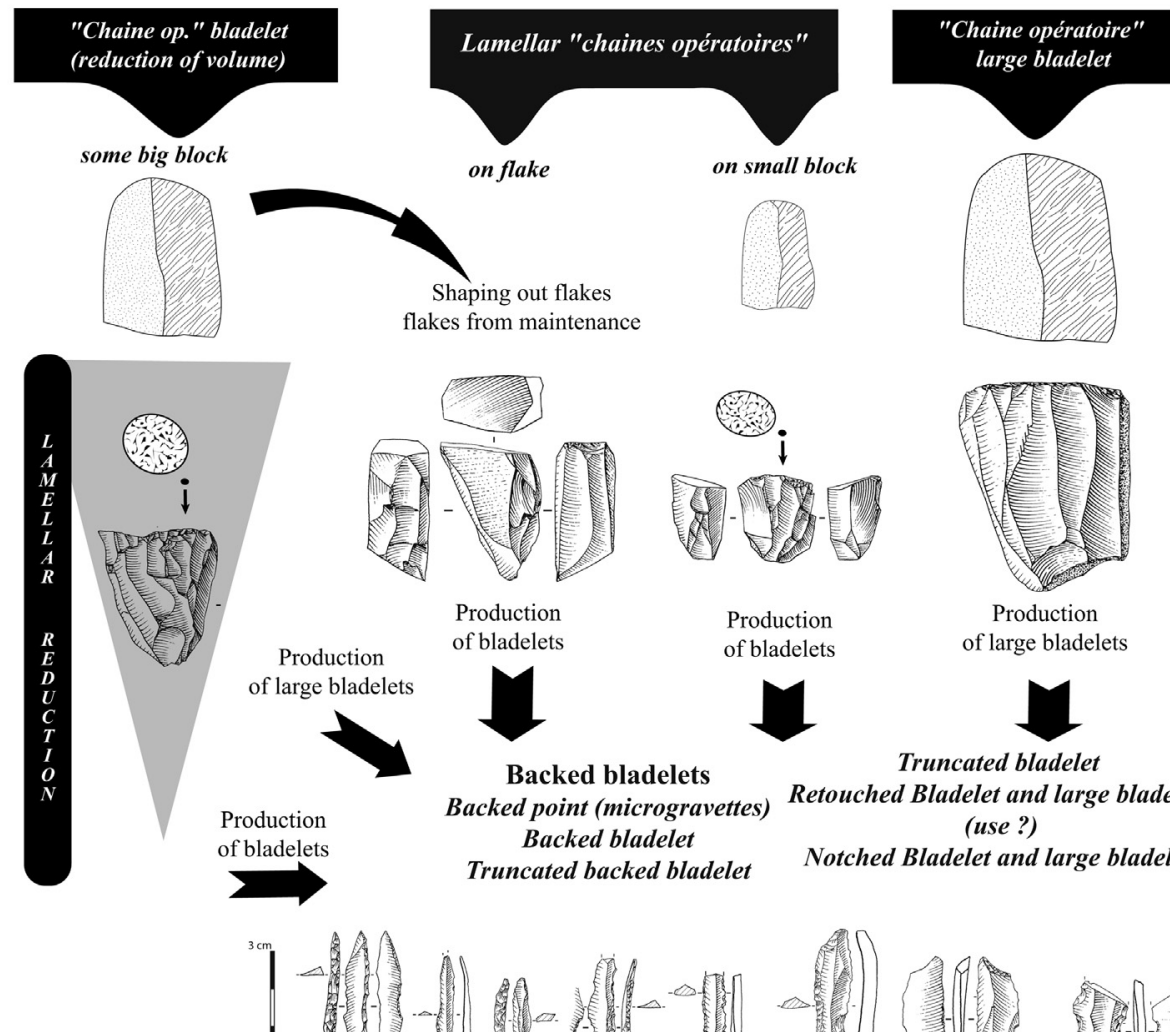

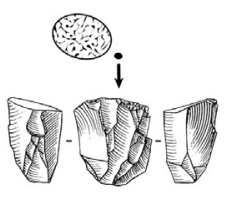

Production of bladelets

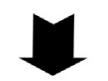

Backed bladelets Backed point (microgravettes) Backed bladelet Truncated backed bladelet

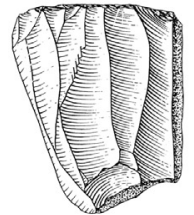

Production of large bladelets

Production of large bladelets
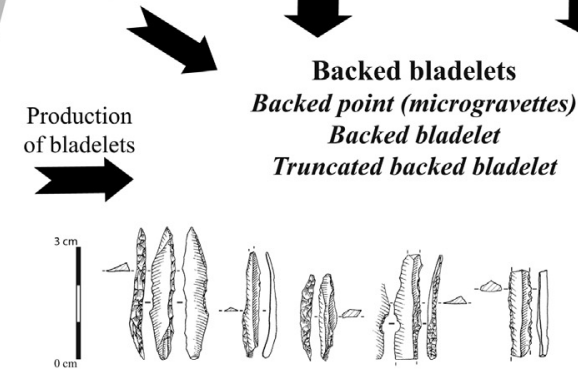

Retouched Bladelet and large bladelet (use?)

Notched Bladelet and large bladelet

Figure 11. Scheme of lithic technical system (computer graphics C. Montoya; drawings of the pieces by G. Devilder). 
their use. Several of them suggest use of the cutting edges of the blades without retouch. A traceological study is envisaged to evaluate the different activities carried out with these objects. In addition to these retouched blades are blades with notches $(N=4)$ and truncation $(N=5)$ (Fig. 11).

\section{The objectives of production}

To understand the objectives, it is necessary to evaluate the dimensional characteristics of the blanks desired by the Epigravettian craftsmen of Kalavan 1. In a particular sample, measurement of the widths of rough blanks for full debitage, whether whole or broken, provides understanding of the objectives for this production. For this, a sample of 193 blade and bladelet blanks from full debitage sequences was examined.

Lithic production at Kalavan 1 was oriented towards producing three types of blanks: bladelets, large bladelets and some blades (Fig. 10). Quantitatively, the blanks of the 'bladelet group' are the most represented in the collection. They consist of two size ranges. The smaller bladelets measure between 2 and $8 \mathrm{~mm}$ wide and are about $40 \mathrm{~mm}$ long. The large bladelets vary from 9 to $17 \mathrm{~mm}$ in width and from 40 to $60 \mathrm{~mm}$ in length (Fig. 10). The few blades or blade fragments vary from 18 to $31 \mathrm{~mm}$ in width. Products with straight profiles were sought, a characteristic common to all the blanks produced.

This bladelets/large bladelets dichotomy has also been described on several Late Glacial Epigravettian sites in northern Italy and south-eastern France (Montoya, 2004, 2008; Montoya and Bracco, 2005; Montoya and Peresani, 2005a,b).

\section{The organisation of debitage and technical methods of production}

Based on the initial observations and before the work of refitting, the lithic technical sub-system appears to be based on four operational chains of production (Fig. 11).

The operations of blade production on obsidian or local rock are partly represented at Kalavan 1 in the form of rare blade blanks. No blade core was brought to light during the different campaigns. The absence of blade cores could be explained by the establishment of a process of blade-bladelet reduction. However, a development of this blade-bladelet system is not seen in the archaeological material. In fact, the lack of both blade cores and a blade-bladelet system of reduction is further validated by the absence of subproducts in the entire lithic collection (flakes from shaping, flakes from maintenance treatment of the debitage surface, tablets...) that would be produced in a chaîne opératoire for obsidian. This makes it difficult to interpret the technical process used to obtain blades. However, there are bipolar distal removals on certain whole blade blanks, which are evidence of the implementation of a second platform for percussion during debitage. The function of the latter as a secondary platform (true bipolar debitage) or a principal platform (alternating unipolar debitage) remains to be evaluated. It is possible that this series of operations for blade production occurred outside the site, in particular for the allochthonous raw materials in obsidian whose sources appear to be diverse and distant (Liagre et al., 2009; Chataigner and Gratuze, 2013a,b). The obsidian blades could have been produced on another site, possibly close to the raw material deposits, and then imported in the form of rough blanks to Kalavan 1. However, the spatial and logistical discontinuity should be observed in the chaîne opératoire for blade production. In the assemblage, there are a few blades made in local rock. Their production could have resulted from the first moments of debitage of blocks by progressive reduction of the volume, intended to produce large bladelets and bladelets. These rare blades obtained from local rocks could have filled occasional needs for the prehistoric group.

Bladelet production on the site is supported by the presence of all of the technical pieces from the different series of operations (core, sub-products, rough products of full debitage, etc.). The examination of the raw materials exploited, based on the bladelet cores that were found, shows a predominance of exploitation of allochthonous materials in obsidian (Table 3 and Fig. 12).

The bladelet debitage involves three chaînes opératoires (Fig. 11). The first is the debitage of blocks, whose length is from 7 to $10 \mathrm{~cm}$. The Epigravettian craftsmen established an integrated process of blank production, which enabled, by progressive reduction of the volume, the production of large bladelets and then bladelets. This chaine operatoire of debitage is seen in the many subproducts, in particular the renewal of striking platforms. For the same raw material (for example, red obsidian), there are several tablets of decreasing size in the collection.

The second chaîne opératoire was mainly developed to obtain bladelets. Implementation began with small blocks or flakes from two origins. They could be diaclastic flakes from the natural fracturation of tectonic rocks in a primary position, which have two parallel fracture surfaces, or flake blanks from cores that were recycled from another chaîne opératoire. The latter were probably sub-products from chaine opératoires for blades or large bladelets (flakes from shaping, tablets, etc.) recycled for bladelet debitage. The narrowest part of these cores was exploited on the cutting edge of the flakes by frontal drawing back of the debitage. For the exploitation of small blocks, the debitage was carried out by superimposition of adjacent bladelet surfaces. This classic method for bladelet production consisted of several sequences, which generated, by intersection of the surface, some bending on the surface of the debitage (Montoya, 2004). This process, considered to be semiturning, enables maintenance of the surface and exploitation of the volume until it is exhausted. The most regular products appear to be produced in the place where the convexity is the most accentuated; that is, from the dihedron formed by the intersection of the two bladelet sequences. Each bladelet sequence successively 'consumes' the lateral convexity provided by the previous sequence. There is thus no particular maintenance of the convexities during the course of the debitage. Moreover, there is a partial readjustment of a guiding flange from a neo-crest.

Whichever the blank used, the operation implemented is of unipolar type. There are several variants. In the majority of cases, the debitage is carried out with the establishment of a single striking platform throughout the working of the piece. In this case, it is a simple unipolar debitage. The opening of a second striking platform is intended to reorient the debitage onto another surface of the volume. In this case, it is a successive unipolar debitage. The second striking platform will then be positioned opposite or

Table 3

Core raw material.

\begin{tabular}{ll}
\hline Kalavan 1 - core raw material & $N$ \\
\hline Obsidians & 27 \\
Spotty red Obsidian & 10 \\
Black Obsidian & 6 \\
Translucent Black Obsidian & \\
Local stones & 5 \\
Green stone - siliceous limestones & 4 \\
Black stone - porphyrites and basalts & 2 \\
Red/brown stone - jaspers & 3 \\
Flint & 57 \\
Total & \\
\hline
\end{tabular}



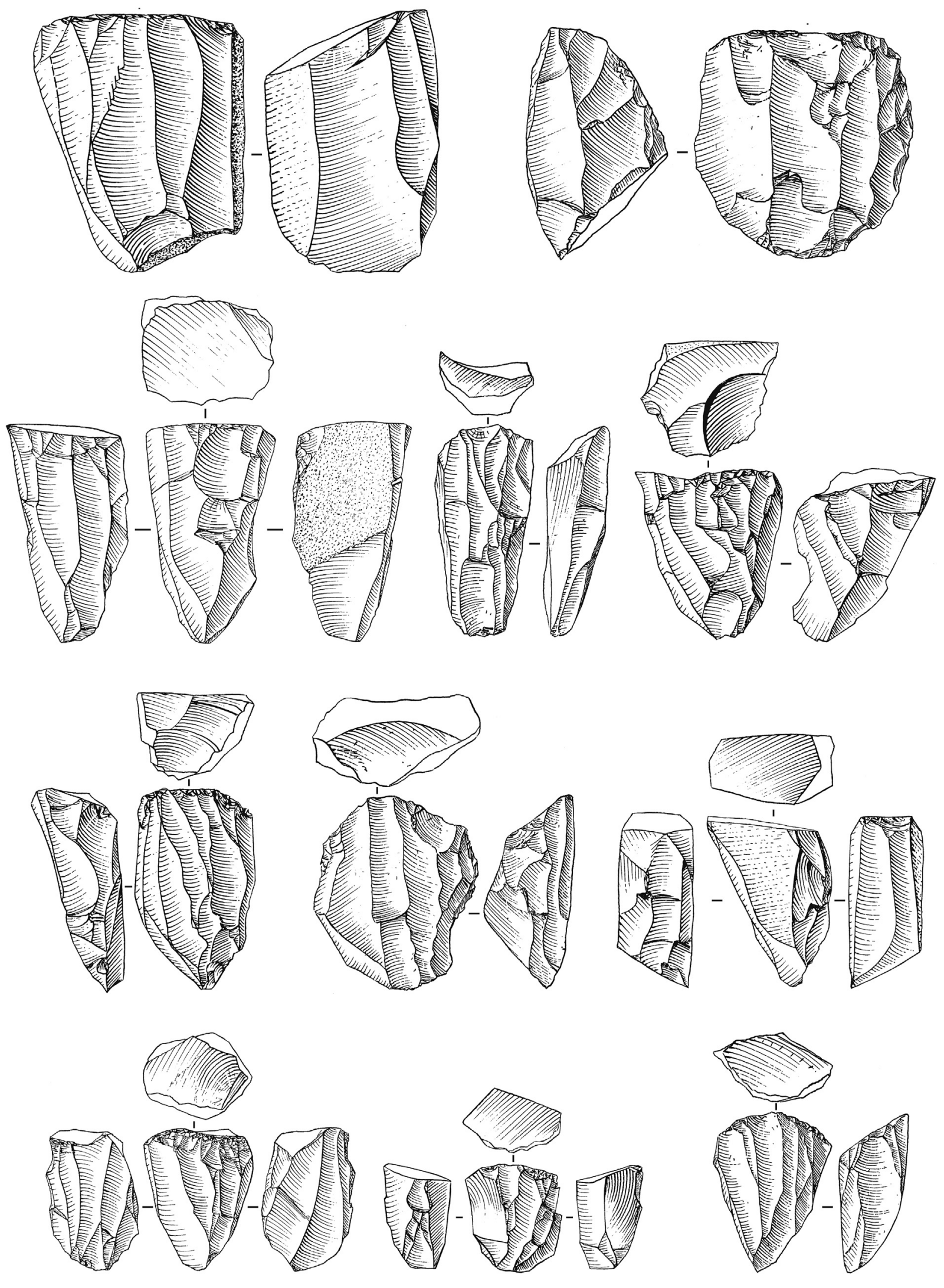

Figure 12. Bladelets cores (drawings by G. Devilder). 
slightly shifted in relation to the line of the first exploitation, or will be situated independently on another surface.

Initial examination of the bladelet blanks and the cores supports the hypothesis of the use of direct percussion on soft stone according to the criteria defined by Pelegrin (2000). Because of the low number of blade pieces, identification of this percussion technique remains to be determined for this chaine opératoire.

\section{Archaeozoological analysis}

\section{Materials and methods}

Anatomical and taxonomic determinations of the Kalavan 1 fauna were carried out for the mammals using Schmid's (1972) methodological system. The remains studied are those of wild animals, especially Caprinae, if we take into account the chronology of the site and the identified faunal spectrum. In this study, we did not have access to comparative data concerning the wild Caprinae of the Caucasus. Consequently, we used currently available domestic species for reference (Ovis aries and Capra hircus) (Boessneck et al., 1964; Prummel and Frisch, 1986; Clutton-Brock et al., 1990). For the teeth, we refer to the work of Payne (1985), Helmer (2000) and Hallstead et al. (2002).

We estimated age according to dental eruption, based on Schmid's work (1972) and dental wear based on the work of Payne (1973) and Helmer (2000). Age profiles, expressed in number of teeth, were set up according to the method proposed in Vigne (1988) and Helmer and Vigne (2004). Because of the relatively limited frequency of bones from young individuals and the taphonomic problems mentioned above, we cannot base any age estimation on the degree of epiphysation, which is highly subject to differential preservation (Vigne, 1984). We are thus limited to using the ages suggested by the teeth.

The total number of faunal remains for level 7 is high (3049 remains; Table 4). Almost all of the material (97.6\%) comes from $7 d 3$. In level $7 d 1$, we only identified three specific remains (4.1\%). For level 7d3, we identified 565 specific fragments (18.6\%).

\section{State of preservation of the material}

The bones were removed with the archaeological sediments in order to better preserve them. Several bones carried calcareous incrustations, which are difficult to remove without destroying the bone itself, thus we decided not to weigh the fragments.

The state of preservation of the faunal material is very poor. The following interpretations must take into consideration the fact that the results are biased in favour of adult individuals rather than the youngest animals and the smallest species. Because of the poor state of preservation, the faunal material was cleaned in a dry state,

Table 4

Distribution of faunal remains found in layer 7 (total), $7 \mathrm{~d} 1$ and $7 \mathrm{~d} 3$.

\begin{tabular}{lrrrrr}
\hline Levels & c7d1 & c7d3 & \multicolumn{3}{c}{ Total level 7 } \\
Species & NR & NR & \multicolumn{1}{c}{$\%$} & NR & $\%$ \\
\hline Wild sheep/wild goat (Ovis sp./Capra sp.) & 3 & 530 & 17.81 & 533 & 17.48 \\
Wild sheep (Ovis sp.) & & 31 & 1.04 & 31 & 1.02 \\
Wild capra (Capra sp.) & 1 & 0.03 & 1 & 0.03 \\
Red deer (Cervus elaphus) & 1 & 0.03 & 1 & 0.03 \\
Bos/Cervus & 1 & 0.03 & 1 & 0.03 \\
Bos/Bison & & 1 & 0.03 & 1 & 0.03 \\
Undetermined medium mammals & 70 & 2396 & 80.51 & 2466 & 80.88 \\
Undetermined large mammals & & 15 & 0.50 & 15 & 0.49 \\
Mammals determined & 73 & 2976 & 100.00 & 3049 & 100.00 \\
\hline
\end{tabular}

as water could have damaged the bones. Some bone fragments could be joined.

Many bones had become altered before becoming buried (for example, erosion, cracking due to changes of temperature, humidity, etc.). Very few pieces (NISP $=15,0.6 \%$ ) present alterations due to fire (burning traces). Only one fragment presents a carnivore tooth pit. Surface alterations could have erased such marks on most of the bones, as well as traces of butchering (skinning, disarticulation, flesh removal). We also discovered bones fractured along their length, presenting percussion marks (point of impact, incipient cone, helicoidal fracture), probably indicating recovery of the bone marrow (Fig. 13). Isolated teeth are well-preserved anatomical elements, as their chemical composition makes them more resistant to the action of various taphonomic factors.

The proportions of the different parts of the long bones of the Caprinae are clearly biased in favour of the diaphyses. The epiphyses, too fragile for good preservation (Binford, 1981; Lyman, 1994), are almost completely absent, strongly limiting the identification of species.

Most of the faunal remains present longitudinal fractures, which may be related to complex taphonomic processes (freezingthawing; humidity-drought, etc.), but also to voluntary fragmentation for extraction of the bone marrow and grease (Lyman, 1994). In our faunal material, no bone presents a whole circumference and $75 \%$ of the bones present less than $30 \%$ of their circumference, evidence of a high level of destruction of the original bone (Bunn, 1982). The length of the unidentified remains is generally between 0 and $2 \mathrm{~cm}(46 \%)$ or between 2 and $5 \mathrm{~cm}(41 \%)$.

\section{Faunal list}

The faunal spectrum identified is extremely poor considering the number of taxa. All of the remains belong to mammals (Table 4). The remains of the identified mammals show a predominance of wild Caprinae (Ovis sp./Capra sp., 533 NISP), among which very few could be attributed to Ovis sp. (31 pieces) or Capra sp. (one pieceone scapula). The spectrum is completed by red deer (Cervus elaphus) and a large bovid (Bos/Bison), with a piece from each of the two species (Table 4).

All of the other unidentified mammal remains (2466 pieces, $80.9 \%$ ) are of similar size to the Caprinae, but could also represent other species (young wild boar, roe deer, medium-sized carnivores,
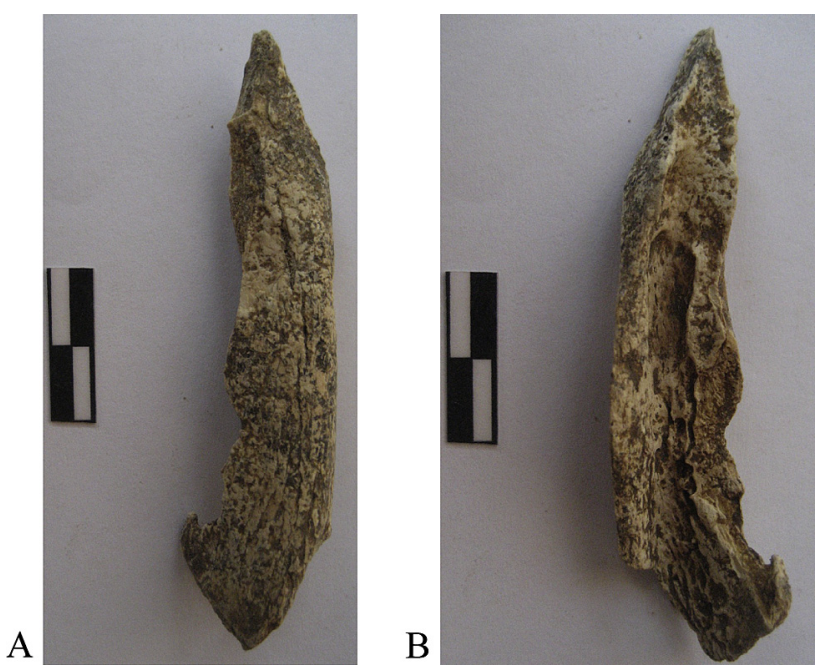

Figure 13. Humerus of a wild caprin (diaphysis), which presents traces of impact indicative of removal of the bone marrow: A - lateral view; B - internal view. 
a.

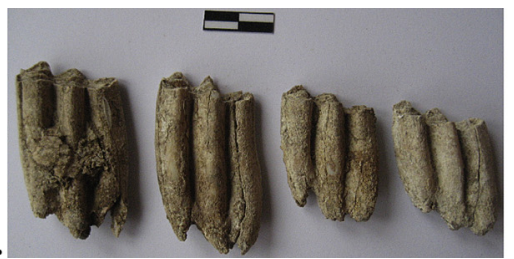

b.

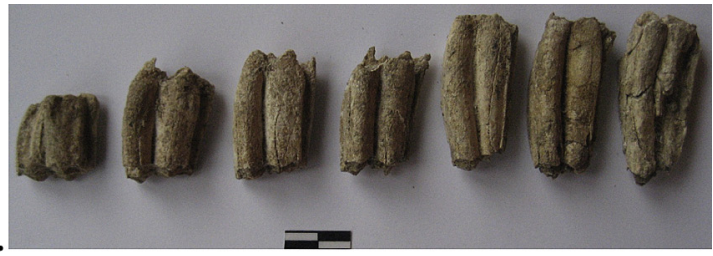

Figure 14. a. Left lower teeth (M3) of wild sheep (lateral view); b. upper right teeth (M3) of wild caprinae (lingual view) discovered in Kalavan c7d3.

etc.). The precise determination of the mammals, particularly Ovis sp., was made only on the basis of the lower teeth (except for one radius). These were found in sufficient quantity to establish the mortality profiles.

The wild sheep species to which the bones may belong is Ovis orientalis gmelini (Armenian mouflon), which is today a threatened species living in Armenia. It is known that two taxa of wild Caprinae are present in the Caucasus: Capra caucasica/cylindricornis (the tur ibex) and Capra aegagrus (the wild goat), but without the scapula it is impossible to differentiate between the two species.

\section{Mortality profiles}

The teeth, better preserved than other elements of the skeleton, enable age determination of the Caprinae at the time of death. The sample of lower and upper teeth studied (161 teeth) is sufficient to construct a mortality profile for the Caprinae discovered in horizon $7 \mathrm{~d} 3$ (Figs. 14 and 15).

The study of the age profiles of the Caprinae (Fig. 15) shows a predominance of animals of class $\mathrm{D}$ (between one and two years) with a percentage of $37 \%$, followed by older animals of class $G$ (between four and six years), at 33\%, and EF (between two and four years) at $27 \%$. We must point out that the age classifications represented in Fig. 16 are corrected. According to these data, Caprinae that have already reached a considerable weight (nearly the maximal weight) appear to be predominant in our sample.

The mortality profile of the wild sheep, based on the lower teeth study (NISP $=80$ ), presents the same tendency in the selection of the animals hunted: the Epigravettian human group hunted animals between one and six years of age (class D - 34\%, EF - $26 \%$ and $\mathrm{G}-35 \%$ ), which had reached a maximum weight, thus providing a large quantity of meat, as well as other products (hide, bone, tendons, blood, intestines, marrow, etc.).

The mortality profiles for the Caprinae found in horizon $7 \mathrm{~d} 3$ show the absence of very young animals, as no teeth of Caprinae aged between birth and two months (class A) or two and six months (class B) have been discovered so far. Thus it appears that the hunters did not seek out the young animals, which did not provide much meat, and it may be that they left them for future hunting in a later season. This could indicate a true hunting strategy that preserved the immature animals.

Unfortunately, it was not possible to identify remains of horn core, evidence for the sex of the animals. Poor preservation of the faunal material and taphonomic processes had destroyed these remains.

The species of Ovis hunted by the Epipalaeolithic community of Kalavan is probably 0 . orientalis gmelini. This species presents strong sexual dimorphism. These animals migrate seasonally, to the high meadows in summer and the lowlands in winter. They prefer the meadows, but are also found in wooded zones. The rutting season occurs between mid-October and the end of November, with a peak of activity in the first part of November; the females give birth to one or two lambs in April (Valdez, 2008).

The observation of mouflons has provided insight into some important behavioural characteristics of the species. Except for the rutting season, the males are more difficult to observe than the females, because they live apart from them. The females form herds of ten to 12 individuals with their young, and usually exploit environments different from those of the males (Cransac and Hewison, 1997).

Based on the ecology and the ethology of this species ( 0 . orientalis gmelini), the Caprinae were probably hunted in the most favourable season, from summer to autumn, during the summer migrations from the valley to the high meadows and vice versa (the site of Kalavan 1 is located at an altitude of $1640 \mathrm{~m}$ ) when they sought the best pastures.

In the Caucasus region, there are a few sites contemporary with Kalavan 1 where the fauna has been analysed: Samertskhle Klde, Gvardjilas Klde (Nioradze and Otte, 2000; Nioradze, 2006) and Dzudzuana - Unit B (Meshveliani et al., 2007). For the fauna at these sites, we observe that the data are very incomplete for Samertskhle Klde and Gvardjilas Klde. Only Dzudzuana cave - Unit B was the subject of a highly relevant analysis (Bar-Oz et al., 2008). The principal characteristic of these sites is the diversity of the faunal spectrum, which contrasts with the low diversity at Kalavan 1: at Gvardjilas Klde, 14 taxa were identified, seven at Samertskhle Klde and 12 at Dzudzuana. The diversity and richness of these Georgian Palaeolithic faunas are probably an indication of the various topographic positions of these sites and the different biotopes near them (valley bed, hill, plain). Their altitudes vary from 340 to $800 \mathrm{~m}$ (Nioradze and Otte, 2000), while Kalavan 1, a mountain site, lies at $1640 \mathrm{~m}$. In addition, the conditions for preservation of bones in caves are better than on open-air sites, which are more exposed to climatic variations (humidity, temperature, etc.).

As high altitude is a determining factor in reduction of the faunal spectrum for medium-sized and large mammals, it may be

TOTAL Ovis/Capra wild undetermined - number of teeth $=161$

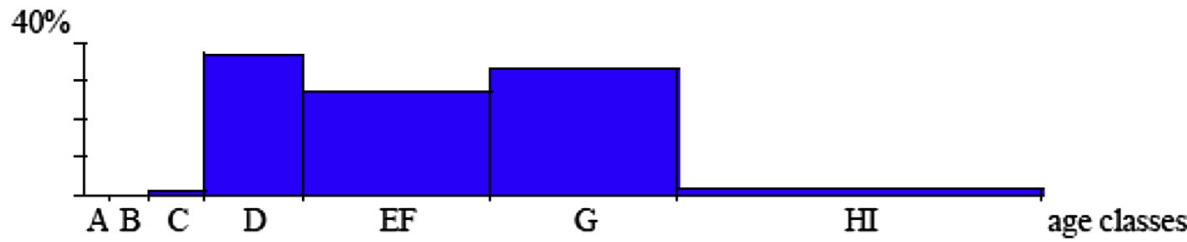

Figure 15. Age profile of Caprinae (Ovis sp./Capra sp.) in classes of age (after Payne, 1973), discovered at Kalavan in 7d3. 

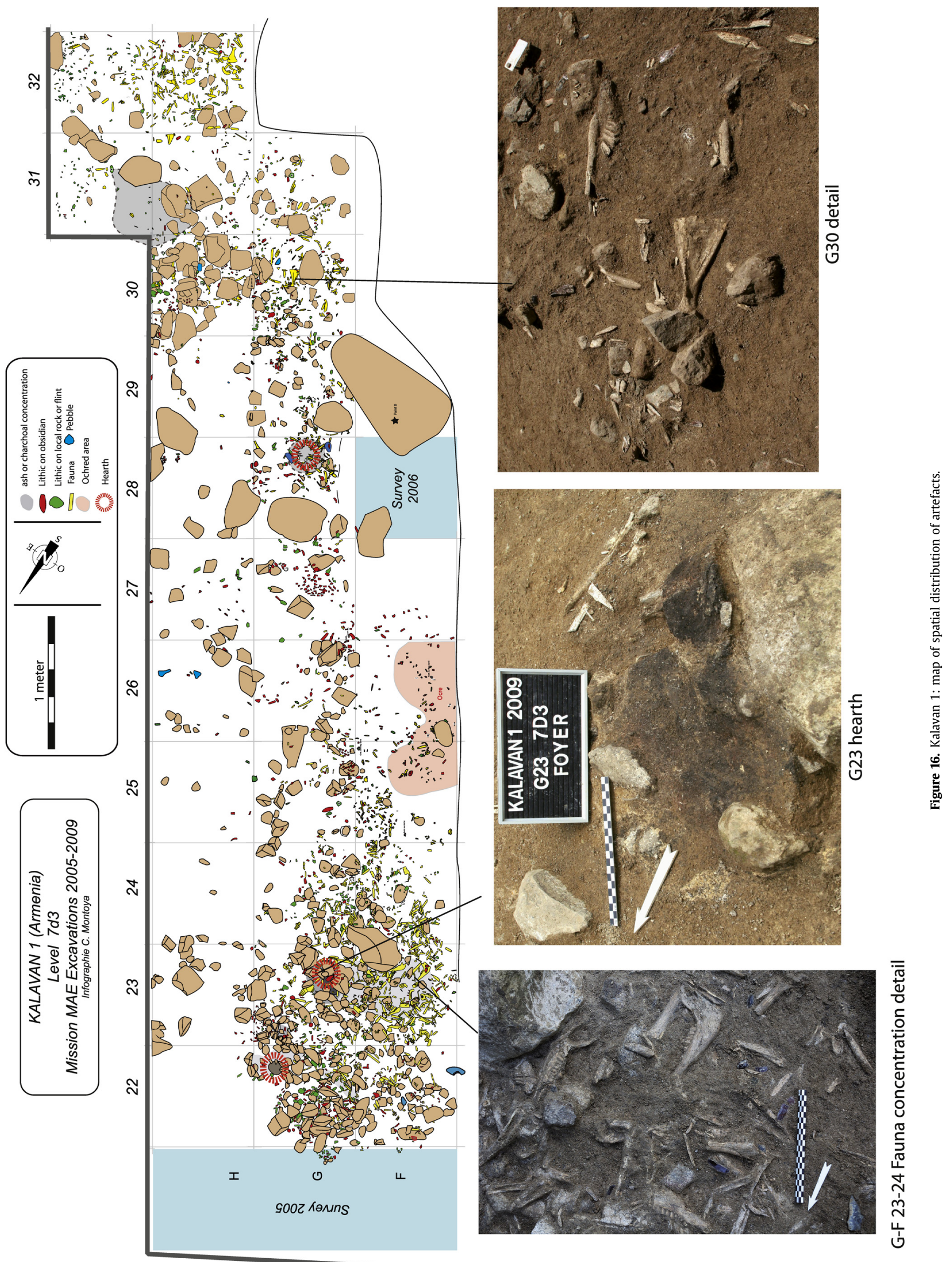

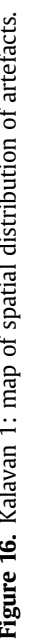


assumed that the list of fauna for Kalavan 1 is appropriate, or rather reflects the mammalian biomass living in this environment 14,000 years BP. However, it is possible to qualify this hypothesis. The faunal spectrum found at Kalavan 1 results from the hunting activity of human groups, and the choices made by them. These choices, which still remain to be determined, were made on the basis of socio-economic and cultural factors. Until complementary analyses are made, the idea of mass hunting of a deliberately reduced spectrum to satisfy specific needs (reserves of meat and hides, etc.) should not be excluded.

At Dzudzuana, the zooarchaeological analysis of level B has shown the predominance of the remains of $C$. caucasica $(50.76 \%)$, followed by those of a large bovid (Bos/Bison - 42.68\%). The zooarchaeological data suggest an occupation of the site between the spring and the autumn. Similar behaviour was revealed at the neighbouring site of Ortvale Klde (Adler et al., 2006), where during the Middle and Upper Palaeolithic, hunting Caprinae (in this case, ibexes, C. caucasica) was predominant (more than $90 \%$ of the fauna).

At Kalavan 1, Ortvale Klde and Dzudzuana, there is the same predominance of artiodactyla species of similar behaviour that migrate seasonally. This was clearly not opportunistic hunting, but rather targeted hunting of one species of ungulate (Adler et al., 2006). It implies both an ethological knowledge of the prey over time (migrations) and space (routes taken), an anticipatory behaviour (being in the right place at the right time), coordination of the group, and selection of suitable weapons for the hunt.

\section{The Epigravettian settlement of Kalavan 1}

In spite of the usual taphonomic problems, the quality of preservation of the vestiges in the layers and the initial examination of their organisation reveal a space of occupation structured by several concentrations of vestiges and three hearths (Fig. 16).

The densest concentration lies within squares G-F 23-24. This is a large mound composed mainly of faunal remains and to a lesser extent, lithics within an ashy, sedimentary matrix (Fig. 16). Most of the vestiges in this mound consist of faunal remains (about 1200), in particular nearly 20 (NISP $=17$ ) mandibles and many dental remains of caprids.

This large mound covered a hearth, located in G-23 (Fig. 16), which is probably the origin of the oblong sandy layer possibly formed by trickling water. This is a flat hearth about $20-30 \mathrm{~cm}$ in diameter, backed against a large block of limestone and surrounded by a few small stones (Fig. 16). The surfaces of most of these stones do not appear to have been altered by heat, which would seem to indicate a relatively brief moderate use. Only two small fragments of burned animal bone were found in the centre of this hearth. The chronologically early date of the hearth and its activity in relation to the mound of fauna above is obvious in light of their mutual stratigraphy, the fact that the mound covers the hearth, and the nearabsence of burned bone in its composition.

The small bowl-shaped hearth in G-22 lies near the mound of faunal remains and the flat hearth G-23. It is a small circular hearth surrounded by several stones that have been heated. The base of the combustion structure has a maximum depth of nearly $7 \mathrm{~cm}$. Its perimeter is marked by several grayish stains, probably the consequence of ashes spreading. As for hearth G-23, the presence of an oblong ashy stain oriented in the line of the slope appears to be the result of trickling water that partly washed out the upper part of the hearth (Fig. 16). A cut made in the upper part shows that the resulting bioturbation may have shifted the contents of the hearth and thus altered any possible microstratigraphic reading. Near this hearth, the distribution of vestiges, mostly lithic, is concentrated within and around a slight depression composed of stones, of approximately $60 \mathrm{~cm}$ in diameter and $5 \mathrm{~cm}$ in depth. It contains a mound rich in lithic blanks mostly less than $1 \mathrm{~cm}$. This mound is made up mainly of rough bladelet products and to a lesser extent, flakes. There is only one fragment from a backed point, a single waste piece from point fabrication (microburin of Krukowski), a dihedral burin axis, a truncated blade and a nucleus for small bladelets. This little depression may have also been a place for waste rejection.

Squares F-25 and F-26 are marked by the presence of an ochred zone red in colour (Fig. 16). It is situated at the edge of the disturbed part of the site, defined by band $\mathrm{E}$. The ochred area is characterised by the presence of a small concentration of backed points $(N=5)$, two bladelet cores and an end-scraper on a bladelet blank. The presence of ochre, three end-scrapers, a retouched blade and a burin in the immediate periphery of this zone suggests an area of activity involving the treatment of skins.

The 2009 excavation revealed a third hearth located within square G-28 (Fig. 16). This flat hearth, about $25 \mathrm{~cm}$ in diameter, is characterised by a sub-circular shape and slight reddening. Several fragments of burned fauna were also found. The associated lithic tools comprise a series of four points, including three distal fragments of microgravettes. Two bladelet cores complete this assemblage.

Sector GH-30 to 32 is positioned on a slight shoulder a few centimetres above the depression of bands F-G-H 21 to 29 (Fig. 16). It also contains a concentration of ten backed points and nine bladelet cores, including a little heap of local green stones with good potential for refitting. A wide charred level, not reddened, was also revealed in squares $\mathrm{H}-\mathrm{I} 31$.

\section{Conclusions and research perspectives}

These initial data demonstrate the strong potential of the site of Kalavan 1. The space appears to be organised around hearths and several concentrations of remains in need of further investigation. Analysis of future lithic refitting and complementary studies should enable in time a more complete understanding of these different structures. At the present time, the Epigravettian site of Kalavan 1 offers preliminary results that are of great interest for the entire Caucasus. The main elements are summarised below.

The site of Kalavan 1 is related to seasonal hunting activity, close to a caprid kill site (Binford, 1980). Situated in a strategic sector, the site is located at the interface between the first alpine meadows and the narrowing of the valley of the Barepat. This valley is locally one of the rare passages between the bottom of the valley of the Getik and the high meadows situated at an altitude of $1900 \mathrm{~m}$. Thus, the site of Kalavan 1 provided a convenient location to watch for the seasonal migrations of the different mammal species living in the mountains of the Lesser Caucasus. The presence of the main anatomical parts (the axial skeleton is under-represented) of the animals reveals hunting activity near the site. Despite poor preservation of the bone surfaces, the faunal remains present many anthropic alterations, especially traces of impact, indicating that bones were broken and the marrow consumed. Analysis of the wear micro-traces on the lithics will elucidate other sub-systems, especially the working of other materials carried out by the craftsmen of Kalavan 1.

Based on this initial study of the origin of the lithic raw materials exploited and their system of production, we propose logistics of nomadism as our preliminary working hypothesis.

All of the operational phases of bladelet production and the shaping of backed bladelets are represented on the site. Bladelet production intended for the preparation and reworking of projectile points appears to have motivated most of the knapping activity on the site. Obsidian is the raw material that was 
preferentially exploited for the production of these blanks. However, local materials occasionally complemented the needs of the knappers. The operational sequence used to produce bladelets is identical for all of the materials worked. However, it is observed that the obsidian cores were the most intensely exploited. The absence of sub-products in the chaîne opératoire of blade production suggests a production of blades that probably occurred where the raw material was located, for obvious reasons of size and weight. These technical elements reveal that a blade kit and some small obsidian blocks were transported to Kalavan 1 for bladelet knapping. The blades were subject to an economic strategy of management for deferred use (Pigeot, 1988; Karlin, 1991), being produced near the obsidian deposits and probably used afterwards at Kalavan 1 . These robust blades with cutting edges would have had a multiple functional potential as they could be used for their cutting quality (retouched blades) and/or transformed into end-scrapers or burins. This behaviour enabled optimisation of the use-weight ratio of the blanks (Kuhn, 1994). The deposits of obsidian are situated for the most part on the other side of Lake Sevan, in the Armenian high volcanic plateaus, at about three to four days' walk for the nearest (Barge and Chataigner, 2004). The high altitude in these supply zones, which are today covered with heavy snow from autumn to spring, limits access except in the mildest season. The Epigravettian groups may have established their first camp in this region at an altitude of more than $2200 \mathrm{~m}$ to obtain the materials and produce blades at the end of spring and/or during the summer. Thus, the occupation of Kalavan 1 may have occurred at the time of the return migration of the caprid herds to the valley bottoms at the end of the summer or during the autumn, before the return of winter. After stocking their provisions for the winter (meat, hides, etc.), the Epigravettian group probably returned to the valley of the Getik or the nearby foothill regions, in what are today Georgia and/or Azerbaijan. This nomadic circuit would have included other logistical stops, but the archaeological evidence is still lacking. However, in the analyses of the origin of the obsidian (Chataigner and Gratuze, 2013a,b), one piece was determined to be from a source south-east of Lake Sevan, at Syunik (Sevkar group) some $100 \mathrm{~km}$ as the crow flies from Kalavan 1. This supply source, if confirmed by other pieces, would not only enlarge the territory covered, but also serve to partly define the nomadic circuit of these prehistoric human groups of the Lesser Caucasus. Other movements and/or trade networks over long distances $(>180 \mathrm{~km})$ in the region of Transcaucasia were determined based on the identification of the sources of obsidian artefacts from MP and UP sites (Chataigner, 1998; Barge and Chataigner, 2004; Golovanova et al., 2012; Le Bourdonnec et al., 2012; Tushabramishvili et al., 2012; Chataigner and Gratuze, 2013a,b).

Kalavan 1 provides significant information on the recolonisation of the high mountains of the Lesser Caucasus after the Last Glacial Maximum. Although the perception of the subsistence behaviours of the hunter-gatherers of the Lesser Caucasus is limited for the time being to the 'window' of Kalavan 1, the initial results argue for a strategy of planned mobility for the acquisition of resources (Féblot-Augustins, 1997, 1999). This strategy of resources acquisition and hunting was affected by the 'constraints' of the natural environment. Obtaining lithic resources of exceptional quality in the high mountains was limited to a short period of the year, and the seasonal migrations of animal herds occurred in other geographic areas of the Lesser Caucasus.

Typological affinity with other Caucasus Epipalaeolithic sites can be observed in the case of straight-backed points. The presence of microgravettes, which were of high cultural value, in all postLGM Caucasus lithics collections appears to be a strong element shared by the human groups of this area (Lioubine, 1989; Nioradze and Otte, 2000; Meshveliani et al., 2004; Bar-Yosef et al., 2011; Golovanova et al., 2012). However, some typological differences need to be mentioned. No geometric armatures or microburins technic were recognised at Kalavan 1 . Geometric microlithics were recognised occasionally on Epipalaeolithic sites in the northern and southern Caucasus (Nioradze and Otte, 2000; Bar-Yosef et al., 2011; Golovanova et al., 2012), at Mezmaiskaya cave (Level 1-3; $12,960 \pm 60 \mathrm{BP}$ and $13,860 \pm 70 \mathrm{BP}$ ) and Satanai rock shelter (horizons $2 \mathrm{~b}-3-4 ; 11,200 \pm 110 \mathrm{BP}, 11,140 \pm 100 \mathrm{BP}, 11,200 \pm 130 \mathrm{BP})$. There is no real shouldered point in Kalavan 1 . There are only four shouldered pieces, which originated accidentally from backed bladelet production (Krukowski microburin).

The typological variability found on the Caucasus Epipalaeolithic sites recently presented by Golovanova et al. (2012) could reflect cultural and/or regional variants or possibly chronological differences. This remains to be evaluated with 'modern' excavation methods, accompanied by analysis of the stratigraphy and taphonomy.

The Gravettian-Epigravettian tradition appears to have been present since the LGM in the Caucasus. The Samerzchle Klde cave has produced a lithic industry with a Gravettian method of knapping, including the production of regular long blades and bladelets, rectilinear in profile, intended, according to the authors, for the making of 'gravettes' and 'microgravettes' (Nioradze and Otte, 2000). The authors specify "rectilinear backed pieces made on blades and bladelets evoke European Gravetian" (Nioradze and Otte, 2000). A dating of bone from the Samerzchle Klde site was obtained recently $(20,160 \pm 160 \mathrm{BP})$. The cave of Gwardzilas Klde also provided levels with several gravette points, microgravettes and a bone industry. Two dates were obtained on fauna from between 16,000 and 15,000 BP. More recently, Meshveliani et al. (2004, 2007) used the term 'Epi-gravettian' to characterise industry with points displaying rectilinear backs from Unit B of the Dzudzuana cave. Several old excavations in Georgia revealed the presence of lithic and bone industries of Gravettian-Epigravettian tradition (Nioradze and Otte, 2000; Nioradze, 2006; Golovanova et al., 2010). Therefore, the existence of an Epigravettian site such as Kalavan 1 in the Lesser Caucasus is not surprising.

\section{Acknowledgements}

The excavations at Kalavan- 1 were funded by the French Ministry of Foreign Affairs and by the Armenian branch of the Gfoeller Foundation, to whom the authors express their sincere thanks. Our thanks to P. Bertrand for fabric analysis, to E. Willcox for the translation from French to English and to L. and N. Haber for the English revision of the text. We also thank the Ghukasyan family and the people of Kalavan. We are grateful to the three anonymous reviewers whose comments helped us to improve the initial text.

\section{References}

Adler, D.S., Tushabramishvili, N., 2004. Middle Paleolithic patterns of settlement and subsistence in the southern Caucasus. In: Conard, N.J. (Ed.), Settlement Dynamics of the Middle Paleolithic and Middle Stone Age, vol. II. Kerns Verlag Tübingen, pp. 91-133.

Adler, D.S., Bar-Oz, G., Belfer-Cohen, A., Bar-Yosef, O., 2006. Ahead of the game Middle and Upper Palaeolithic hunting behaviors in the southern Caucasus. Curr. Anthropol. 47, 89-118.

Barge, O., Chataigner, C., 2003. The procurement of obsidian: factors influencing the choice of deposits. J. Non-Cryst. Sol. 323, 172-179.

Barge, O., Chataigner, C., 2004. Un SIG pour l'analyse des approvisionnements l'exemple de l'obsidienne de l'Arménie. Rev. Archéom. 28, 25-33.

Bar-Oz, G., Belfer-Cohen, A., Meshveliani, T., Djakeli, N., Bar-Yosef, O., 2008 Taphonomy and zooarchaeology of the Upper Palaeolithic cave of Dzudzuana, Republic of Georgia. Int. J. Osteoarchaeol. 18, 131-151. 
Bar-Yosef, O., Belfer-Cohen, A., Mesheviliani, T., Jakeli, N., Bar-Oz, G., Boaretto, E., Goldberg, P., Kvavadze, E., Matskevich, Z., 2011. Dzudzuana: an Upper Palaeolithic cavesite in the Caucasus foothills (Georgia). Antiquity 85, 331-349.

Bertran, P., Texier, J.-P., 1995. Fabric analysis: application to Paleolithic sites. J. Archaeol. Sci. 22, 521-535.

Bertran, P., Lenoble, A., 2002. Fabriques des niveaux archéologiques: méthode et premier bilan des apports à l'étude taphonomique des sites paléolithiques. Paléo 14, 13-28.

Binford, L.R., 1980. Willow smoke and dogs' tails: hunter-gatherer settlement systems and archaeological site formation. Am. Antiq. 45, 4-20.

Binford, L.R., 1981. Bones: Ancient Men and Modern Myths. Academic Press, New York.

Boessneck, J., Muller, H.H., Teichert, M., 1964. Osteologische Unterscheidungsmerkmale zwischen Schaf (Ovis aries Linne) und Ziege (Capra hircus Linne). Kuhn-archiv 78, 1-129.

Bronk Ramsey, C., 2005. OxCal Program V3. 10. Radiocarbon Accelerator Unit University of Oxford.

Bunn, H.T., 1982. Meat-eating and human evolution: Studies on the diet and subsistance patterns of Plio-Pleistocene hominids in East Africa. Ph.D Dissertation, University of California.

Chataigner, C., 1998. Sources des artefacts du Proche-Orient d'après la caractérisation géochimique des artefacts archéologiques. In: Cauvin, M.-C., Gourgaud, A Gratuze, B., Arnaud, A., Poupeau, G., Poidevin, J.-L., Chataigner, C. (Eds.), L'Obsidienne au Proche et Moyen Orient: du Volcan à l'Outil. B.A.R. Int. Ser. 738 273-324. Oxford.

Chataigner, C., Barge, O., 2008. Quantitative approach to the diffusion of obsidian in the ancient northern Near East. In: Posluschny, A., Lambers, K., Herzog, I. (Eds.) Layers of Perception. Proceedings of the 35th International Conference on Computer Applications and Quantitative Methods in Archaeology (CAA), Berlin, Germany, April 2-6, 2007. Kolloquien zur Vor- und Frühgeschichte 10, 375. Dr. Rudolf Habelt, Bonn.

Chataigner, C., Gratuze, B., 2013a. New data on the exploitation of obsidian in the southern Caucasus (Armenia, Georgia) and eastern Turkey. Part 1: source characterization. Archaeometry. http://dx.doi.org/10.1111/arcm.12006.

Chataigner, C., Gratuze, B., 2013b. New data on the exploitation of obsidian in the southern Caucasus (Armenia, Georgia) and eastern Turkey. Part 2: obsidian procurement from the Upper Palaeolithic to the Late Bronze Age. Archaeometry. http://dx.doi.org/10.1111/arcm.12007.

Clutton-Brock, J., Dennis-Bryan, K., Armitage, P.A., Jewell, P.A., 1990. Osteology of the Soay sheep. Bull. Br. Mus. Nat. Hist. 56, 1-56.

Cour, P. 1974. Nouvelles techniques de détection des flux et de retombées polliniques: étude de la sédimentation des pollens et des spores à la surface du sol. Pollen Spores 16, 103-141.

Cransac, N., Hewison, A.J.M., 1997. Seasonal use and selection of habitat by mouflon (Ovis gmelini): comparison of the sexes. Behav. Process. 41, 57-67.

Féblot-Augustins, J., 1997. La Circulation des Matières Premières au Paléolithique vol. 2. ERAUL 75, Liège.

Féblot-Augustins, J., 1999. La mobilité des groupes paléolithiques. Bull. Mém. Soc. Anthropol. Paris 11, 219-260.

Ghukasyan, R., Colonge, D., Nahapetyan, S., Ollivier, V., Gasparyan, B., Monchot, H., Chataigner, C., 2011. Kalavan 2 (north of Lake Sevan, Armenia): a new late middle Paleolithic site in the lesser Caucasus. Archaeol. Ethnol. Anthropol. Eurasia 38, 39-51.

Golovanova, L.V., Doronichev, V.B., Cleghorn, N.E., 2010. The emergence of boneworking and ornamental art in the Caucasian Upper Palaeolithic. Antiquity $84,299-320$

Golovanova, L.V., Doronichev, V.B., Cleghorn, N.E., Koulkova, M.A., Sapelko, T.V., Shackley, M.S., Spasovskiy, Yu.N., 2012. The Epipaleolithic of the Caucasus after the Last Glacial Maximum. Quatern. Int.. http://dx.doi.org/10.1016/ j.quaint.2012.04.034

Hallstead, P., Collins, P., Isaakidou, V., 2002. Sorting the sheep from the goats: morphological distinctions between the mandibles and mandibular teeth of adult Ovis and Capra. J. Archaeol. Sci. 29, 545-554.

Helmer, D., 2000. Discrimination des genres Ovis et Capra a l'aide des prémolaires inférieures 3 et 4 et interprétation des âges d'abattage: l'exemple de Dikili Tash (Grèce). Anthropozoologica 31, 29-38.

Helmer, D., Vigne, J.-D., 2004. La gestion des cheptels de caprinés au Néolithique dans le Midi de la France. In: Bodu, P., Constantin, C. (Eds.) Approches Fonctionnelles en Préhistoire. Actes XXVe Congres Préhistoriques Français, Nanterre, 24-26 nov. 2000. Société Préhistorique Française, Paris, pp. 397-407.

Joannin, S., Cornée, J.J., Münch, P., Fornari, M., Vasiliev, J., Krijgsman, W., Nahapetyan, S., Gabrielyan, Y., Ollivier, V., Roiron, P., Chataigner, C., 2010. Early Pleistocene climatic cycles in continental deposits of the Lesser Caucasus of Armenia inferred from palynology, magnetostratigraphy, and ${ }^{40} \mathrm{Ar} /{ }^{39} \mathrm{Ar}$ dating. Earth Planet. Sci. Lett. 291, 149-158.

Kandel, A.W., Gasparyan, B., Bruch, A.A., Weissbrod, L., Zardaryan, D., 2011. Introducing Aghitu-3, the first Upper Paleolithic cave site in Armenia. Armenian J. Near East. Stud. VI, 7-23.

Karlin, C., 1991. Analyse d'un processus technique: le débitage laminaire des Magdaléniens de Pincevent (Seine et Marne). In: Mora, R., Terradas, X., Parpal, A. Plana, C. (Eds.), Tecnologia y Cadenas Operativas Liticas, Treballs d'Arqueologia 1. Universitat Autònoma de Barcelona, Barcelona, pp. 125-162.

Kuhn, S.L., 1994. A formal approach to the design and assembly of mobile toolkits. Am. Antiq. 59, 426-442.
Le Bourdonnec, F.X., Nomade, S., Poupeau, G., Guillou, H., Tushabramishvili, N., Moncel, M.-H., Pleurdeau, D., Agapishvili, T., Voinchet, P., Mgeladze, A., Lordkipanidze, D., 2012. Multiple origins of Bondi Cave and Ortvale Klde (NW Georgia) obsidians and human mobility in Transcaucasia during the Middle and Upper Palaeolithic. J. Archaeol. Sci. 39, 1317-1330.

Liagre, J., Arakelyan, D., Gasparyan, B., Nahapetyan, S., Chataigner, C., 2009. Mobilité des groupes préhistoriques et approvisionnement des matières premières à la fin du Paléolithique supérieur dans le Petit Caucase: données récentes sur le site de plein air de Kalavan 1 (nord du lac Sevan, Arménie). In: Acte du XVe Congrès UISPP, Lisbonne, 4-9 Septembre 2006, pp. 75-84.

Lioubine, V.P., 1989. Paleolit Kavkasa. In: Boriskovsky, P.I. (Ed.), Paleolit Mira. Paleolit Kavkaza i Severnoi Azii. Nauka, Leningrad, pp. 7-142.

Lioubine, V.P., 1992. Human adaptation in the mountain environments of the Caucasus during Upper Paleolithic and Mesolithic. Preistoria Alpina 28, 207-219.

Lyman, R.L., 1994. Vertebrate Taphonomy. Cambridge University Press, Cambridge.

Meshveliani, T., Bar-Yosef, O., Belfer-Cohen, A., 2004. The Upper Paleolithic in western Georgia. In: Brantingham, P.J., Kuhn, S.L., Kerry, K.W. (Eds.), The Early Upper Paleolithic Beyond Western Europe. University of California Press, Berkeley, pp. 129-143.

Meshveliani, T., Bar-Oz, G., Bar-Yosef, O., Belfer-Cohen, A., Boaretto, E., Jakeli, N., Koridze, I., Matskevich, Z., 2007. Mesolithic hunters at Kotias Klde, western Georgia: preliminary results. Paléorient 33, 47-58.

Montoya, C., 2002. Les pointes à dos épigravettiennes de Saint-Antoine-Vitrolles (Hautes-Alpes): diversité typologique ou homogénéité conceptuelle? Bull. Soc. Préhist. Fr 99, 275-287. http://www.persee.fr/web/revues/home/prescript/ article/bspf_0249-7638_2002_num_99_2_12657.

Montoya, C., 2004. Les traditions techniques lithiques à l'Epigravettien. Ph.D. Dissertation, Université de Provence.

Montoya, C., 2008. Apport de l'analyse technique à la compréhension de l'évolution des groupes humains épigravettiens d'Italie Nord Orientale: la production lithique de l'US 15a-65 du Riparo Dalmeri. Preistoria Alpina 43, 191-208. http:// www.mtsn.tn.it/pubblicazioni/7/43/11b_Montoya.pdf.

Montoya, C., Bracco, J.-P., 2005. L'industrie lithique du site épigravettien de SaintAntoine à Vitrolles (Hautes-Alpes). In: Bracco, J.-P., Montoya, C. (Eds.), D'un monde à l'autre: Les systèmes lithiques pendant le Tardiglaciaire autour de la Méditerranée nord-occidentale: actes de la table ronde internationale à Aix-enProvence (6-8 juin 2001), Mém. Soc. Préhist. Fr 40, pp. 81-94.

Montoya, C., Peresani, M., 2005a. Nouveaux éléments de diachronie dans l'Epigravettien récent des Préalpes de la Vénétie. In: Bracco, J.-P., et Montoya, C. (Eds.), D'un monde à l'autre : les systèmes lithiques pendant le Tardiglaciaire autour de la Méditerranée nord-occidentale: actes de la table-ronde internationale, Aixen-Provence, 6-8 juin 2001, Mém. Soc. Préhist. Fr 40, pp. 123-138.

Montoya, C., Peresani, M., 2005b. Premiers éléments d'analyse technologique de l'industrie lithique du gisement épigravettien de Val Lastari (Préalpes de la Vénétie). In: Bracco, J.-P., Montoya, C. (Eds.), D’un monde à l'autre: les systèmes lithiques pendant le Tardiglaciaire autour de la Méditerranée nord-occidentale: actes de la table-ronde internationale, Aix-en-Provence, 6-8 juin 2001, Mém. Soc. Préhist. Fr 40, pp. 103-121.

Nioradze, M. 2006. Le Paléolithique supérieur de la Géorgie (2001-2005). In: Noiret, P. (Ed.), Le Paléolithique Supérieur Européen Bilan Quinquennal 20012006. Actes du XVe Congrès UISPP, Lisbonne, 4-9 Septembre 2006. ERAUL 115, Liège, pp. 9-15.

Nioradze, M.G., Otte, M., 2000. Paléolithique supérieur de Géorgie. L’Anthropologie 104, 265-300.

Ollivier, V., Nahapetyan, S., Roiron, P., Gabrielyan, I., Gasparyan, B., Chataigner, C., Joannin, S., Cornée, J.-J., Guillou, H., Scaillet, S., Munch, P., Krijgsman, W., 2010. Quaternary volcano-lacustrine patterns and paleobotanical data in southern Armenia. Quatern. Int. 223-224, 312-326.

Payne, S., 1973. Kill-off patterns in sheep and goat: the mandibles from Asvan Kale. Anatolian Stud. 23, 281-303.

Payne, S., 1985. Morphological distinction between the mandibular teeth of young sheep, Ovis and goats, Capra. J. Archaeol. Sci. 12, 139-147.

Pelegrin, J., 2000. Les techniques de débitage laminaire au Tardiglaciaire: critères de diagnose et quelques réflexions. In: Valentin, B., Bodu, P., Christensen, M. (Eds.), L'Europe Centrale et Septentrionale au Tardiglaciaire: Confrontation des Modèles Régionaux de Peuplement. Actes de la Table-Ronde Internationale de Nemours, 14-16 mai 1997, Mémoires du Musée de Préhistoire d'lle-de-France 7. Nemours, pp. 73-86.

Pigeot, N., 1988. Magdaléniens d'Etiolles: Économie de Débitage et Organisation Sociale. CNRS, Paris.

Prummel, W., Frisch, H.J., 1986. A guide for the distinction of species, sex and body in bones of sheep and goat. J. Archaeol. Sci. 13, 567-577.

Reimer, P.J., Baillie, M.G.L., Bard, E., Bayliss, A., Beck, J.W., Bertrand, C.J.H. Blackwell, P.G., Buck, C.E., Burr, G.S., Cutler, K.B., Damon, P.E., Edwards, R.L., Fairbanks, R.G., Friedrich, M., Guilderson, T.P., Hogg, A.G., Hughen, K.A., Kromer, B., McCormac, G., Manning, S., Bronk Ramsey, C., Reimer, R.W., Remmele, S., Southon, J.R., Stuiver, M., Talamo, S., Taylor, F.W., van der Plicht, J., Weyhenmeyer, C.E., 2004. IntCal04 terrestrial radiocarbon age calibration, 026 cal kyr BP. Radiocarbon 46, 1029-1058.

Schmid, E., 1972. Atlas of Animal Bones. Elsevier, Amsterdam.

Tushabramishvili, N., Pleurdeau, D., Moncel, M.-H., Agapishvili, T., Vekua, A., Bukhsianidze, M., Maureille, B., Muskhelishvili, A., Mshvildadze, M., Kapanadze, N., Lordkipanidze, D., 2012. Human remains from a new Upper Pleistocene sequence in Bondi Cave (western Georgia). J. Hum. Evol. 62, 179-185.

Valdez, R., 2008. Ovis Orientalis, IUCN 2010. In: IUCN Red List of Threatened Species. Version 2010.4 www.iucnredlist.org (accessed 08.05.11.). 
Vigne, J.-D., 1984. Premières données sur les débuts de l'élevage du Mouton, de la Chèvre et du Porc dans le sud de la Corse (France). In: Clutton-Brock, J. Grigson, C. (Eds.), Animals and Archaeology, 3. Early Herders and Their Flocks. B.A.R. Int. Ser. 202, 47-65. Oxford
Vigne, J.-D., 1988. Les Mammifères Post-Glaciaires de Corse. CNRS, Paris. Walker, M.J.C., Björck, S., Lowe, JJ., Cwynar, L.C., Johnsen, S., Knudsen, K.-L. Wohlfarth, B., INTIMATE group, 1999. Isotopic 'events' in the GRIP ice core: a stratotype for the Late Pleistocene. Quatern. Sci. Rev. 18, 1143-1150. 